Binghamton University

The Open Repository @ Binghamton (The ORB)

$11-1-2011$

\title{
Greenlaw's Suakin: The Limits of Architectural Representation and the Continuing Lives of Buildings in Coastal Sudan
}

Nancy Um

Binghamton University--SUNY, nancyum@binghamton.edu

Follow this and additional works at: https://orb.binghamton.edu/art_hist_fac

Part of the Architectural History and Criticism Commons, Historic Preservation and Conservation Commons, and the History of Art, Architecture, and Archaeology Commons

\section{Recommended Citation}

Nancy Um, "Greenlaw's Suakin: The Limits of Architectural Representation and the Continuing Lives of Buildings in Coastal Sudan," African Arts 44:4 (Winter 2011): 36-51.

This Article is brought to you for free and open access by the Art History at The Open Repository @ Binghamton (The ORB). It has been accepted for inclusion in Art History Faculty Scholarship by an authorized administrator of The Open Repository @ Binghamton (The ORB). For more information, please contact ORB@binghamton.edu. 


\section{(1)}

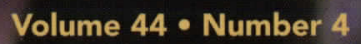
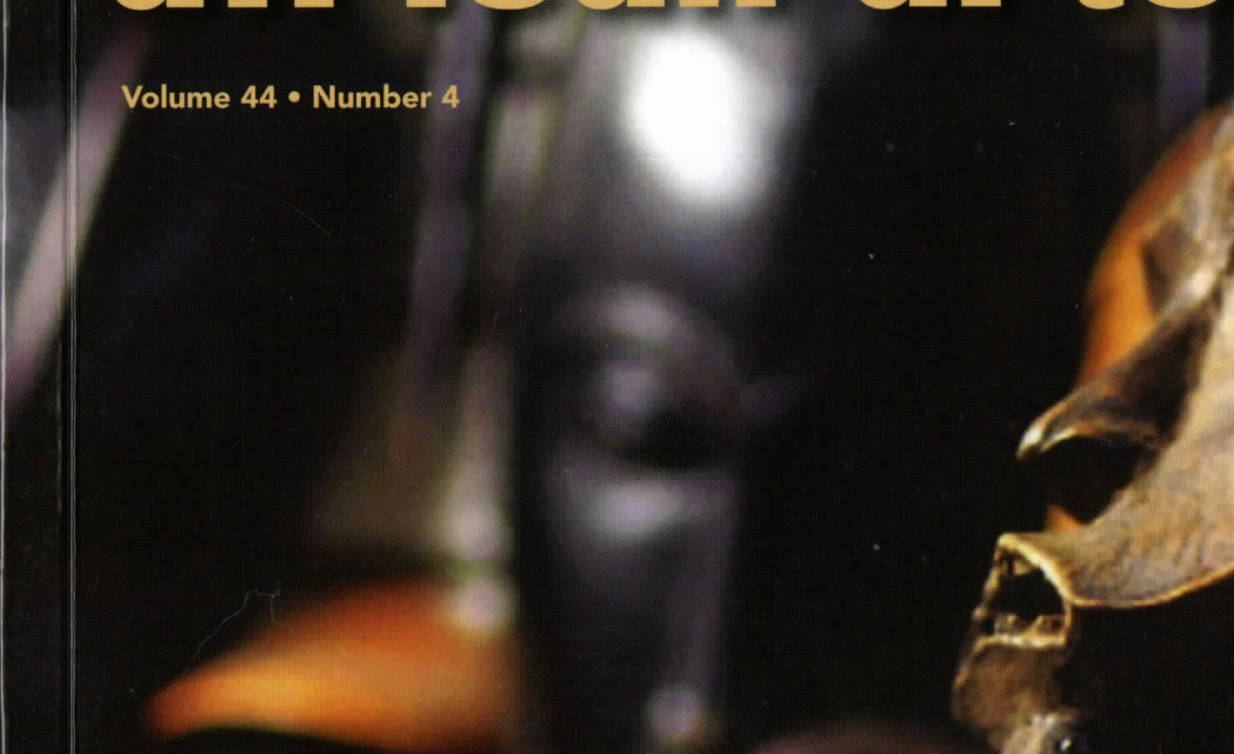


\section{african arts}

\section{UCLA}

\section{Objects of Desire}

Shopping for Identity and the Meaning of Africa

at the Harlem Market

Zain Abdullah

22 Bruce Onobrakpeya and the

Harmattan Workshop

Artistic Experimentation in the Niger Delta

Janet Stanley

36 Greenlaw's Suakin

The Limits of Architectural Representation and the

Continuing Lives of Buildings in Coastal Sudan

NANCY UM

52 Dance, Image, Myth, and Conversion in the Kingdom of Kongo, 1500-1800

CÉCILE Fromont

64 Dancing Identity

Gregory Maqoma's Beautiful Me

66 Identity, Diversity and Modernity in

an Urban Cultural Cocktail

Gregory MAQOMA

72 Beautiful Me/We

Gregory Maqoma and Ubuntu

Catherine M. Cole

Memory and Identity and the Threshold in Gregory Maqoma's Beautiful Me

Mary (Polly) Nooter Roberts

African Arts is devoted to the study and discussion of traditional, contemporary, and popular African arts and expressive cultures. Since 1967, African Arts readers have enjoyed high-quality visual depictions, cutting-edge explorations of theory and practice, and critical dialogue. Each issue features a core of peer-reviewed scholarly articles concerning the world's second largest continent and its diasporas, and provides a host of resources--book and museum exhibition reviews, exhibition previews, features on collections, artist portfolios, and dialogue and editorial columns. The journal promotes investigation of the connections between the arts and anthropology, history, language, literature, politics, religion, and sociology.

All articles have been reviewed by members of the editorial board.

Published by

The James S. Coleman African Studies Center

UCLA International Institute

\section{DEPARTMENTS}

first word

$1 \quad$ Introducing jOSS

LesLie ElLen Jones

in memoriam

4 The Elephant Lies Down Like a Hill

Tribute to Ulli Beier, 1922-2011

ROWLAND ABIODUN

exhibition reviews

Man Ray, African Art, and the Modernist Lens

Vancouver, BC

REVIEWED BY BRIANNE HOWARD

84 Africa Interweave-Textile Disaporas

Gainesville, FL

REVIEWED BY BERNHARD GARDI

87 When Last I Wrote to You about Africa

Toronto, CA

Reviewed by Risham Majeed and Giulia Paoletti

book reviews

90 Ousmane Sembène

by Samba Gadjigo

REVIEWED BY JELANi (W.M. HAMM)

91 The Beautiful Time

by Bogumil Jewsiewicki

REVIEWED BY Francine WeISS

92 Zulu Basketry

by Jannie van Heerden

REVIEWED BY IAN WILSON

93 Representing Africa in American Art Museums edited by Kathleen Bickford Berzock and Christa Clarke REVIEWED BY CAROL MAGEE

94 African Film

by Manthia Diawara

Reviewed by Sheila Petty

96 advertiser index

cover Higher priced art inside stall shop at the Harlem Market, New York. (See p. 16.)

PHOTO: SHARJEEL KASHMIR 


\title{
Greenlaw's Suakin
}

\section{The Limits of Architectural Representation and the Continuing Lives of Buildings in Coastal Sudan}

\author{
Nancy Um
}

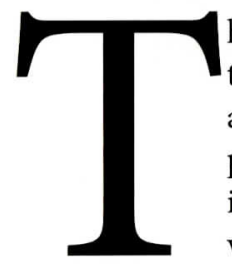

he island city of Suakin on Sudan's Red Sea coast thrived as a center of trade and pilgrimage from at least the thirteenth century during the Mamluk period. Then, after coming under Ottoman rule in the early sixteenth century, the city became a vital node in the transregional maritime matrices that connected the Mediterranean to the Indian Ocean and inland Africa to Mecca. In 1869, the opening of the Suez Canal further bolstered Suakin's key coastal position. But the port's fortunes shifted in 1909 when the British constructed Port Sudan to Suakin's north. Shortly afterward, trade operations moved to the newly built port and Suakin's merchants eventually vacated the city, leaving their distinctive houses, built of coral-rock quarried directly from the shoreline, to deteriorate. Today, there are no inhabitants left on the island, only architectural ruins. ${ }^{1}$

Despite its ruined state, Suakin's architecture is well known internationally, particularly among archaeologists and those who study vernacular building. This enduring reputation may be attributed largely to The Coral Buildings of Suakin, a copiously illustrated text published by the artist Jean-Pierre Greenlaw (1910-1982) in 1976 and then reprinted in 1995 with a new subtitle and foreword. Hailed at the time of its original issuance as the "finest published contribution in English to Sudanese art history," it has been used widely as a source for the architecture of the connected regions of the Arab world, the Red Sea, East Africa, and the Indian Ocean (Hale 1977:5) With its handdrawn plans, elevations, sections, and architectural details of the houses, mosques, and public structures of Suakin, the text has almost single-handedly retained the memory of a lost tradition of vernacular building.
This study represents an effort to look closely at the images that fill The Coral Buildings, which was not a scholarly work, but nevertheless has served as a classic resource for the architecture of a city that is now destroyed. A reassessment of Greenlaw's wider visual project, which was not simply a transparent documentary effort, is now timely for several reasons. After arriving at Bakht al-Ruda training college in Sudan in 1936 to integrate drawing and crafts into the primary school curriculum, Greenlaw went on to become a major figure in Sudan's colonial education system and art world (Clark 1977:45). Most notably, in 1946, he established the School of Design at Gordon Memorial College, Sudan's first art program at the level of higher education. ${ }^{2}$ There, he worked with fellow teachers Shafiq Shawqi and Osman Waqialla to train local students in art and design. Of his protégées, Ibrahim El Salahi, who would later become the leading artist of the Khartoum School, is undoubtedly the most famous (Clark 1977:46, Hassan 1995:109-110). Now that the legacies of his Sudanese colleagues and students have been canonized in the rewriting of a globalized modern art, a study of this transformative mentor and educational reformer is due.

Moreover, since 2002, Sudanese and international scholars and archaeologists have engaged in the Suakin Project, which is a government-sponsored initiative that has overseen successive excavations at the site in order to prepare selected monuments for reconstruction (rather than preservation) and to transform Suakin into a major tourist destination. ${ }^{3}$ There is no question that heritage specialists will consult Greenlaw's corpus of images as they determine how to rebuild the city for a contemporary audience. ${ }^{4}$ For this reason, the images that appear in The Coral Buildings require focused scrutiny. 


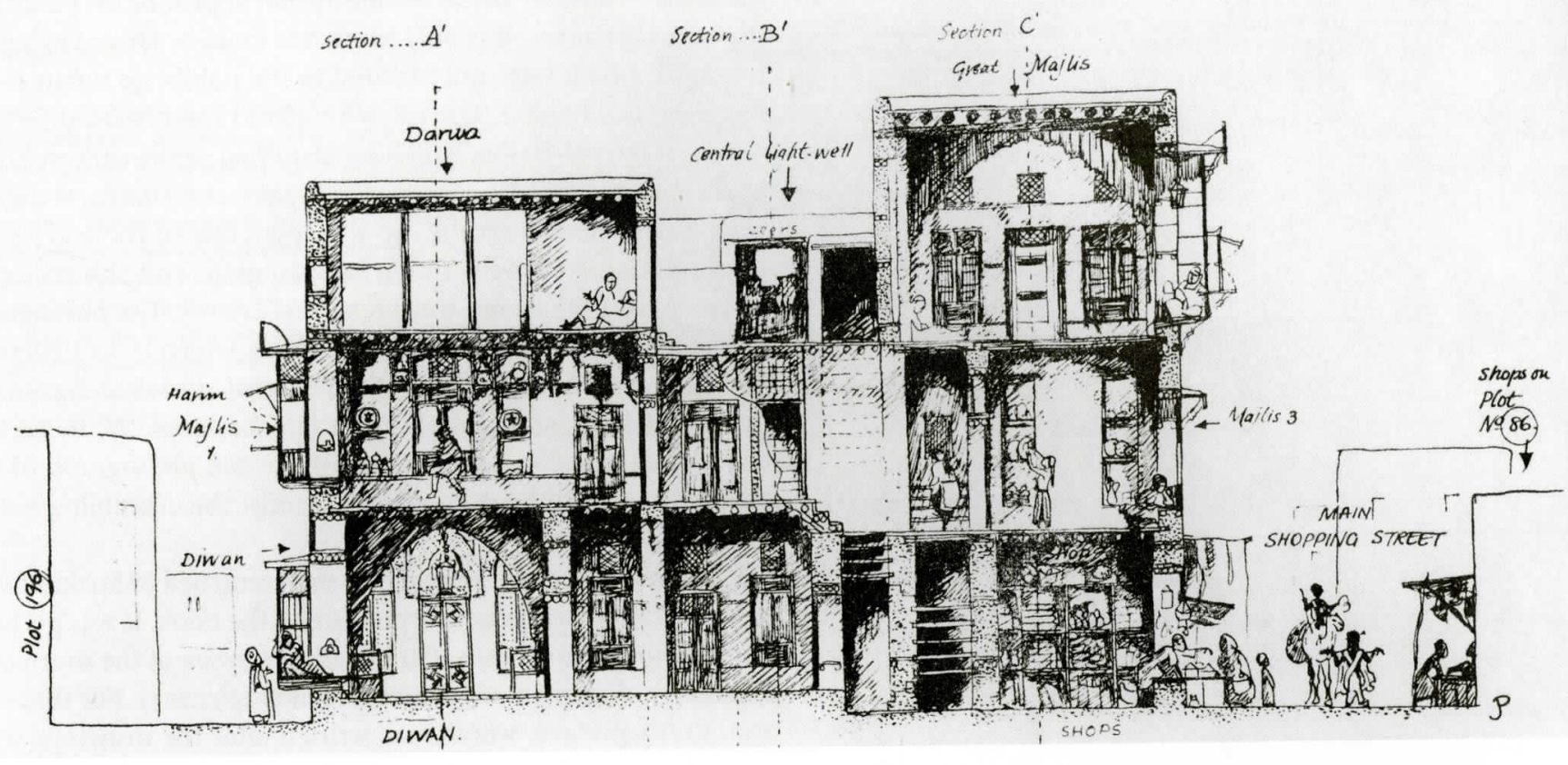

1 Section, Bayt Shinawi Bey, Suakin, Sudan GREENLAW 1995:34

Greenlaw's published drawings represent a city bustling with activity, despite the fact that Suakin's heyday as a port had long passed and most of the houses that he saw in the 1940s and 1950s were uninhabited and in ruins.

2 Diwan or sitting room, Bayt al-Basha, Suakin, Sudan GREENLAW 1995:25

In this drawing, Greenlaw reinstated the arch to its former state, and removed any signs of decay, but also highlighted the room's fine visual details, such as the corbelling under the arch and the relief work in the spandrels.

3 Diwan or sitting room, Bayt al-Basha, Suakin, Sudan

GREENLAW, 1945-51. REPRODUCED COURTESY OF THE GREENLAW ARCHIVE, GRE P081.01, SUDAN ARCHAEOLOGICAL RESEARCH SOCIETY, LONDON

The photograph shows the stone arched diwan as Greenlaw saw it: degraded, filled with rubble, and requiring a wooden strut as support. This image stands in sharp contrast to Figure 2, which represents the room in a pristine state and emphasizes its architectural ornament.
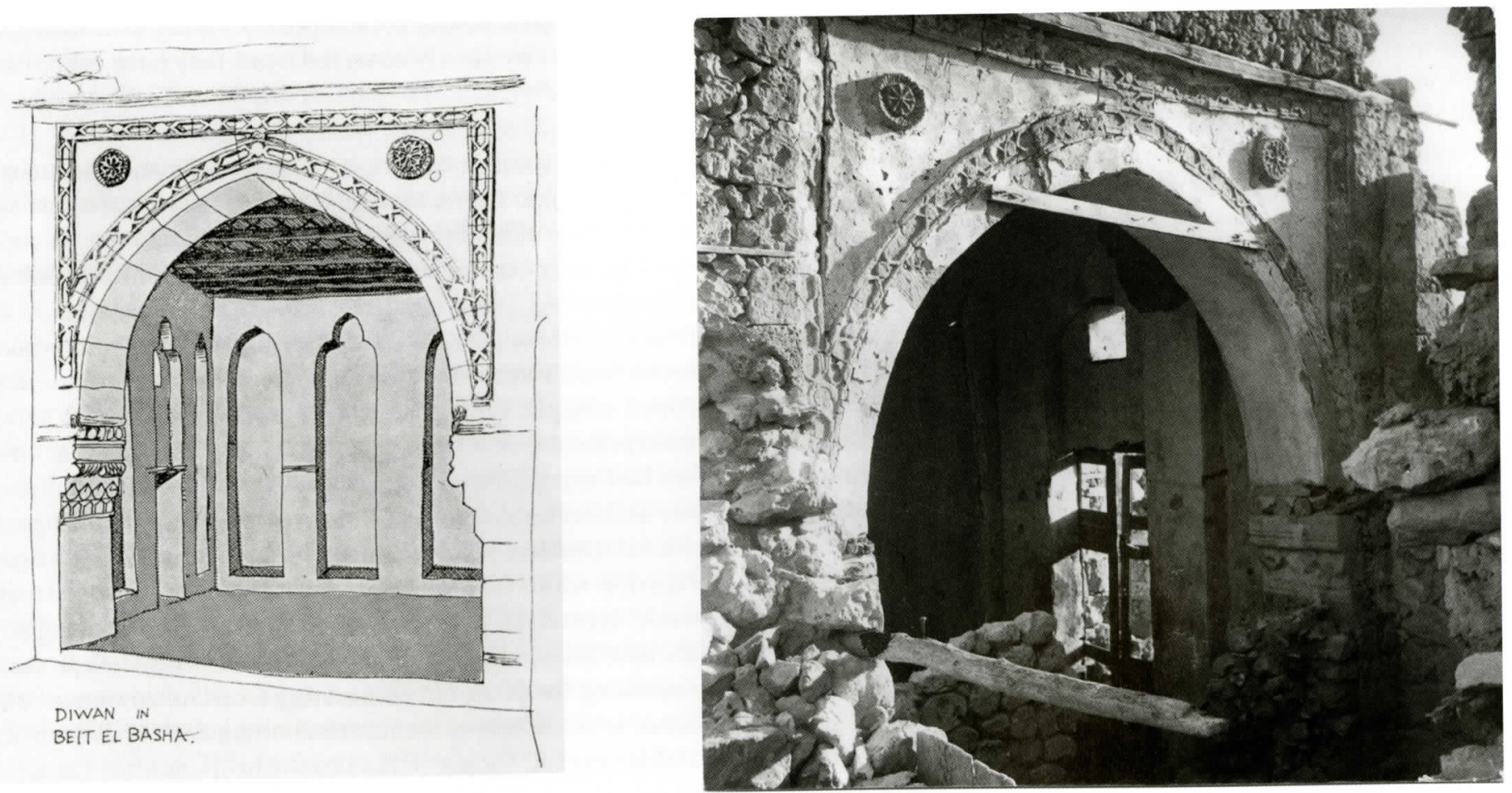
EARLIER AND LARGER TURKISH HOUSES
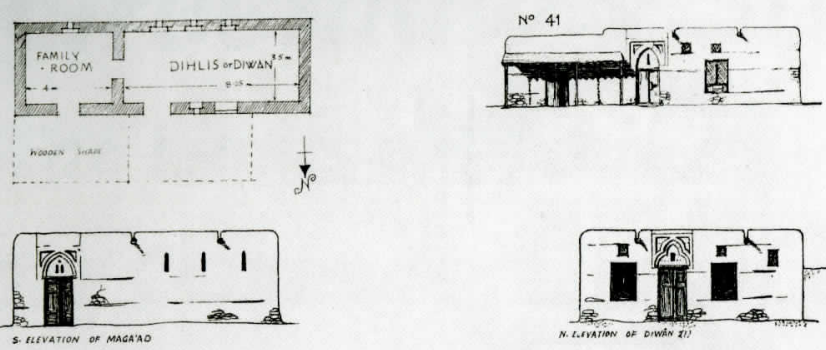

s.

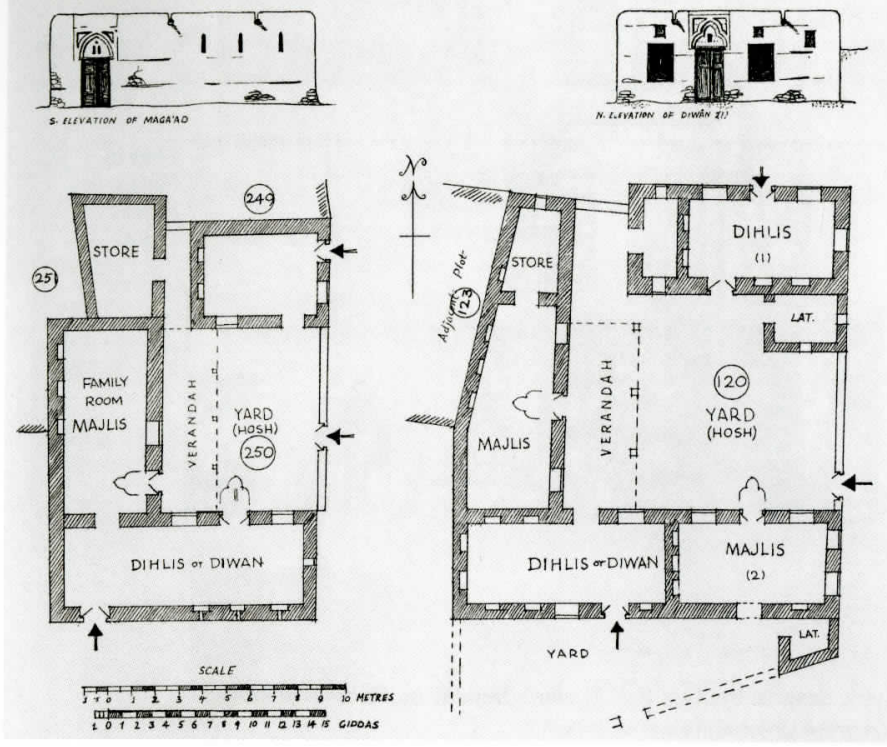

4 Plans and elevations, "original-type houses,"

Suakin

GREENLAW 1995:23

Although Greenlaw, in his text, attempted to disavow his images as documentary sources, his plans, elevations, and sections use the conventions of technical drawings, thereby presenting a fiction of accuracy and measured exactitude.

\section{THE IDEA OF DOCUMENTATION}

In order to understand Greenlaw's approach to the city of Suakin, one must look closely at the artist's stated goals, which map out the orientation of his project. As Greenlaw presented it, his images were not renderings of a city observed in the 1940 s and early 1950 s when he spent time there. Rather he intended to represent the city at its peak, which he identified as the turn of the twentieth century. As such the book stands as a true "memorial" to the city's past grandeur, as the archaeologist P.S. Garlake called it, with the houses restored to pristine condition, camel caravans returned to the city's bustling streets, and stores replenished with copious commodities, as featured in Figure 1 (Garlake 1978:306). Of course, by the time of Greenlaw's sojourns in Suakin when commercial activity had ceased and most of the city's buildings had deteriorated, the conceptualization of these scenes rested upon a certain amount of imaginative reinvention.

But, because the text does not feature a single photograph in it, it is difficult to keep Greenlaw's retrospective visual approach in mind when perusing the images. ${ }^{5}$ Essentially, the city's past and the artist's present are collapsed seamlessly in the meticulously detailed drawings that appear to rely on the faculty of direct observation. The stark break between the specimens that the artist witnessed and the subjects that appear in his published drawings becomes clear only when one looks to Greenlaw's photographs, which were not featured in the published volume. For instance, in Figure 2, Greenlaw rendered the diwan, or sitting room, of Bayt al-Basha, which he identified as the earliest house in the city, as a pristine yet vacated space. Architectural details, such as the carved rosettes in the spandrels of the wide arch, the undulating corbels under its springing, and the tall open niches inside the room, were rendered crisply. The photograph in Figure 3 reveals a very different habitat, which lacks structural integrity as indicated by the wooden strut stretched across the top of the arch and the rubble that fills the room. While certain ornamental details may be observed in the photograph of the room, they are difficult to discern amidst the crumbling building's surroundings.

Greenlaw left Sudan in 1951, but then returned to Suakin twice to check his drawings before publishing the book. It was perhaps during those return visits that he became aware of the shortcomings of his documentary project (Hinkel 1992:223). For that reason, in his preface, which was written after the drawings were completed, he disavowed his images as documentary sources, hoping to salvage their value as subjective works of art that could be appreciated on their visual merits. In a disclaimer about his capacity as a draftsman, he asserted that his "interest was mainly aesthetic and he was not concerned, at the outset, with scrupulous accuracy of detail and measurement." Moreover, he stated that he relied upon his training as an artist, rather than a surveyor, in this effort (Greenlaw 1995:6). But his last-minute disclaimers were at odds with the visual approach employed in his drawings, particularly the plans, elevations, and sections, which carried the conventions of measured architectural diagrams, such as window apertures, doorswings, directional markers, and scales, calculated in both the metric system and the local unit of measurement, the gidda (Fig. 4). Despite his self-professed nostalgic yearnings or aesthetic objectives, the images of The Coral Buildings appear to the contemporary viewer as documentary sources of a city closely observed. And they have been used as such by modern scholars, particularly because the images have been consulted much more widely than the text.

However, some reviewers, such as Garlake and the archaeologist of Islamic Cairo, George Scanlon, raised questions about the accuracy of his drawings because they could not be verified through extant examples and were not accompanied by substantiating photographs (Garlake 1978:306, Scanlon 1997:112). In 1992, Friedrich Hinkel, the fastidious German archaeologist who surveyed Suakin in 1968 and 1976, offered a more serious and sustained critique, calling Greenlaw's technical drawings "fanciful misrepresentations." In particular, Hinkel asserted that Greenlaw had approximated most of his measurements and distorted key architectural features. ${ }^{7}$ On the other hand, Hinkel praised the information provided in the architectural details, such as Figure 5, which he found to be "most useful for reconstruction work" (1992:223). More recently, archaeologists working at the site have echoed this two-sided critique of Greenlaw's project, by dismissing the plans but committing a certain amount of confidence to the details of architectural ornament ${ }^{8}$ (Mallinson 2004, Mallinson et al. 2009:479, Phillips forthcoming). 
5 Two rawshans, or projecting wooden windows, Suakin, Sudan

GREENLAW 1995:104

While Greenlaw has been criticized for the inaccuracy of his plans, elevations, and sections, he has been praised for his renderings of architectural details, particularly of wood and plasterwork. In such details, isolated elements are rendered with close attention to design features and the texture of the materials used. However, they are shown as disconnected from their built context as individual specimens. In this manner, they bear a strong resemblance to the assemblage of architectural salvage pieces that were installed in the Muhafaza museum as visible in Figure 17.

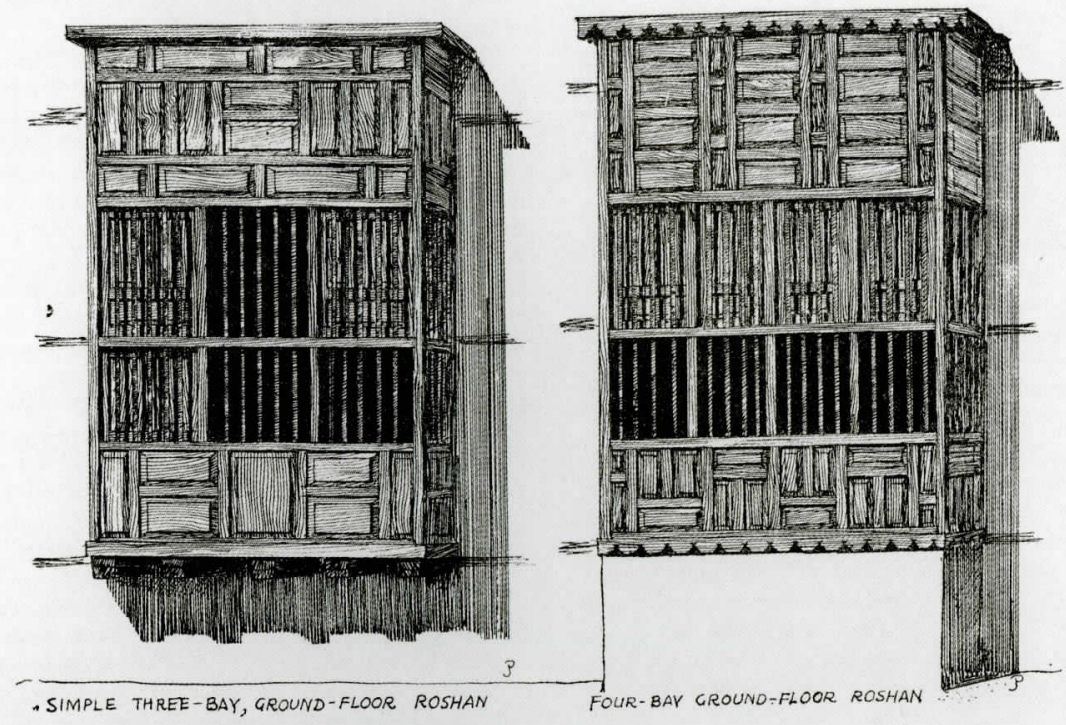

For the reasons mentioned above, I will not read these images through the lens that Greenlaw provided, as primarily aesthetic or nostalgic reflections. But I will also resist reiterating the words of his critics by simply underlining Greenlaw's many inaccuracies in documentation. Rather, I would like to unpack the logic of Greenlaw's visual project even further, with the goal of understanding the conditions under which these images were produced. Essentially, Greenlaw's objective to return a nearly destroyed city to its past state did not entail the simple deletion of later changes to Suakin's fabric or a straightforward reconstruction of buildings that had collapsed. In order to bring these buildings back in time, Greenlaw had to cope with the complex dimensions of urban change, which were tightly intertwined with its historic buildings. This process required that he address not only the decay that came with Suakin's advanced structural decline, but also the later developments that were brought to the city as it moved into the modern era. Essentially, Greenlaw's images are not "wrong" as some might have it, but instead represent the challenges of shutting down the temporal life of buildings in a dynamic city that resisted such definitive closure, even after its presumed heyday.

This project offers a path to consider how architectural documentation functions and to question the orientation and conceptual underpinnings behind seemingly transparent technical drawings and photographs. Following the lines of Tapati GuhaThakurta's study of early photographs and drawings of Indian monuments, I seek to examine the fundamental intersection between the documentation of architecture and the temporal crises that define the writing of architectural history (GuhaThakurta 2003, 2004). Indeed, architectural drawings and photographs may serve as fruitful documents of structures now lost or altered, but moreover, must be conceived of as dynamic representations which, like all representations, operate according to a set of conditions that exist outside of the subject depicted and the image's surface. This study also addresses the temporal con- straints that undergird Orientalist depictions of the East. As the classic critique tells us, the Orientalist eye locates the colonized East in the past, fundamentally unsynchronized with the pace of modernization. Indeed, as indicated above, Greenlaw's renderings adopt this backward-looking stance. But the challenge is to understand how such a past may be constructed pictorially, particularly in the realm of architecture. In the case of Suakin, Greenlaw could not simply turn back the wheels of time to a previous moment in the city's history, but rather had to generate criteria by which he could invent a plausible image of a Suakin that was already lost. His retrospective agenda was extremely complex and needs to be unraveled on its own terms. While this framing may appear to locate Greenlaw within a conventional colonial critique, lined up with past generations of Orientalists and colonial scholars studying places such as Egypt or India, my goal is not to assimilate Greenlaw to these existing paradigms. Rather my interest is to represent the locally specific limits of vision that characterized this artist's documentary project through a focused analysis of a sampling of his images. Greenlaw took on Suakin as an enduring preoccupation at a crucial moment in the port's history and his vision of the city has largely shaped our contemporary understanding of its built dimensions.

\section{STRUGGLING WITH ARCHITECTURAL CHANGE: BAYT KHURSHID EFFENDI}

In order to understand the underpinnings of Greenlaw's visual project, one must delve into the dominant ideas about the chronology of Suakin's architecture that circulated among the many observers who visited the city and documented it in print during the mid and late twentieth century. In addition to Greenlaw, Derek H. Matthews, the architect who restored the famously inaccessible monastery Debre Damo in Ethiopia, was a major figure. Matthews surveyed Suakin for the colonial Public Works Department in the 1950s, spearheaded the idea of the "Red Sea style" based on the city, and then designed the Baladiya building, 


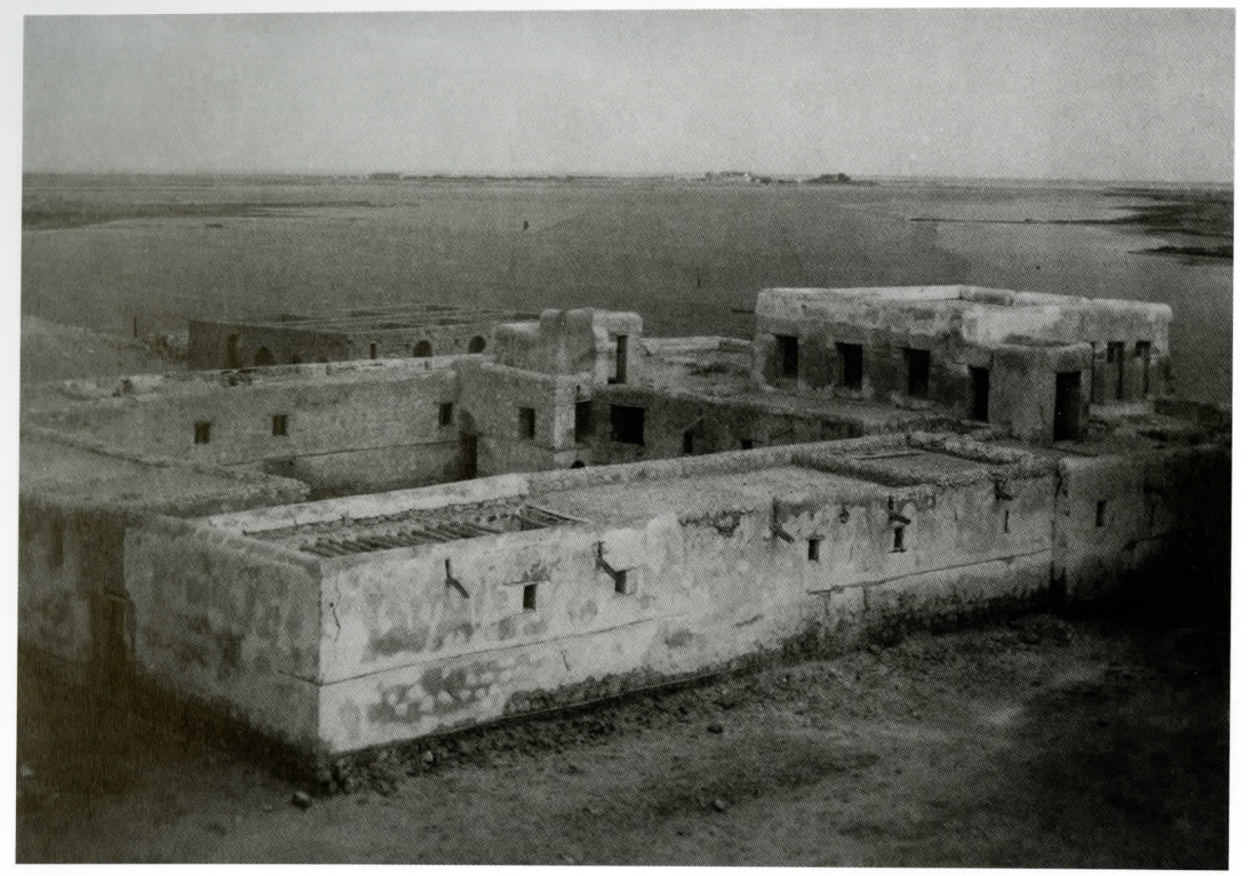

6 Bayt Khurshid Effendi, taken from the southwest from the roof of a neighboring house, Suakin, Sudan

GREENLAW, 1945-51. REPRODUCED COURTESY OF THE GREENLAW ARCHIVE, GRE P148.02, SARS, LONDON

For Greenlaw, Bayt Khurshid Effendi represented Suakin's "original-type" architecture with its low-lying plan and sprawling footprint. On the right edge of the photograph, the shadow of the neighboring National Bank of Egypt building looms

or Town Hall, in the city of Omdurman on the Nile using iconic forms from Suakin's architectural language (Matthews 1953, 1955; Um 2010). In addition, E. Hansen, who wrote a report for UNESCO in 1973, and Hinkel, who reported to the Sudan Antiquities Service after independence, echoed these ideas (Hansen 1973, Hinkel 1992). It is impossible to trace a lineage for the concepts outlined below because many of these figures shared basic assumptions about the development of Suakin's buildings. In their texts and footnotes, they mentioned frequent contacts with one another and liberally cited each other's work (even before publication). ${ }^{9}$

This conservative developmental scheme proposed that there were three major stages in Suakin's architectural evolution. Single-story houses, exemplified by Bayt Khurshid Effendi in Figure 6 , were identified as "original type houses" with low-lying elevations and extended architectural footprints (Greenlaw 1995:22). Although only evidenced by a few remaining examples, it was suggested that these specimens were built as early as the sixteenth century, just before or right after the Ottomans arrived in Suakin. The next stage included what were known as "Turkish houses," when elevations began to rise up multiple stories and most buildings became more compact. Additionally, during this phase projecting wooden windows, or rawshans, dominated house façades. This type, featured in Figure 7, flourished after the Turks took the port in the sixteenth century and ended in the nineteenth when Suakin was brought formally under the aegis of Cairo. The nineteenth century ushered in the last architectural stage in Suakin, the Egyptian period, which facilitated Europeanizing motifs. In this period, the buildings became blockier and open balconies with railings replaced the decorative projecting rawshans, as visible in Figure 8.

Although this staged model was shared by a wide group of architectural specialists, Greenlaw provided concrete examples to support it and infused it with strong feelings about the rise, peak, and then qualitative decline of Suakin's architecture. He was particularly critical of the final stage, the Egyptian style. ${ }^{10}$ He saw the nineteenth-century appearance of the West as a taint on traditional architecture, disdaining the "over-elaborate and finicky decoration" that he witnessed from this era. Ultimately, he dismissed most of these later examples under the subtitle "Signs of Decadence," a designation that clearly reveals his stance on the waning quality of Suakin's buildings into the modern era. It is important to note that Greenlaw based his dating of the houses that served as the armature for this model only on comparative stylistic evidence, rather than epigraphic or foundational documents. Even so, some of his basic assessments in regard to date are being confirmed by modern archaeology. ${ }^{11}$ But for our purposes, the minute details of dating and development are less important than the chronological challenges and built inconsistencies that rendered this scheme unwieldy and unstable, as well as the kinds of historical assumptions that this staged model rested upon.

Here a few words about Suakin's modern history are needed, not only to highlight Greenlaw's struggles with the temporal qualities of the architecture that he observed, but also to provide an understanding of the historical backdrop of colonial Suakin. In fact, Suakin's particularly complicated coastal history, which was not always matched with that of the inland Nile Valley, resisted a model driven by a straight narrative timeline. For instance, the Ottomans had ruled Suakin since the early sixteenth century, but after Muhammad 'Ali of Egypt (who ruled nominally as the sultan's pasha) invaded Sudan in 1821, the city of Suakin moved between Ottoman and Egyptian authority more than once, thereby undermining a clear break between the Turkish and Egyptian eras (Talhami 1979:viii). Sudan only became a formal Egyptian colony, ceded by the Ottoman sultan, in 1865 . But local ambivalence about this era of shifting authority is underlined by the fact that the Sudanese refer to the whole period of nineteenth-century Turk- 
7 West façade, Bayt Shinawi Bey, Suakin, Sudan GREENLAW, 1945-51. REPRODUCED COURTESY OF THE GREENLAW ARCHIVE, GRE P083.01, SARS, LONDON

Greenlaw cast Bayt Shinawi Bey as an example of the "Turkish style," which he viewed as the architectural peak of Suakin's development. In the lower right corner, one can see the place where the rawshan was replaced with a door to make the museum in the diwan directly accessible to the public.

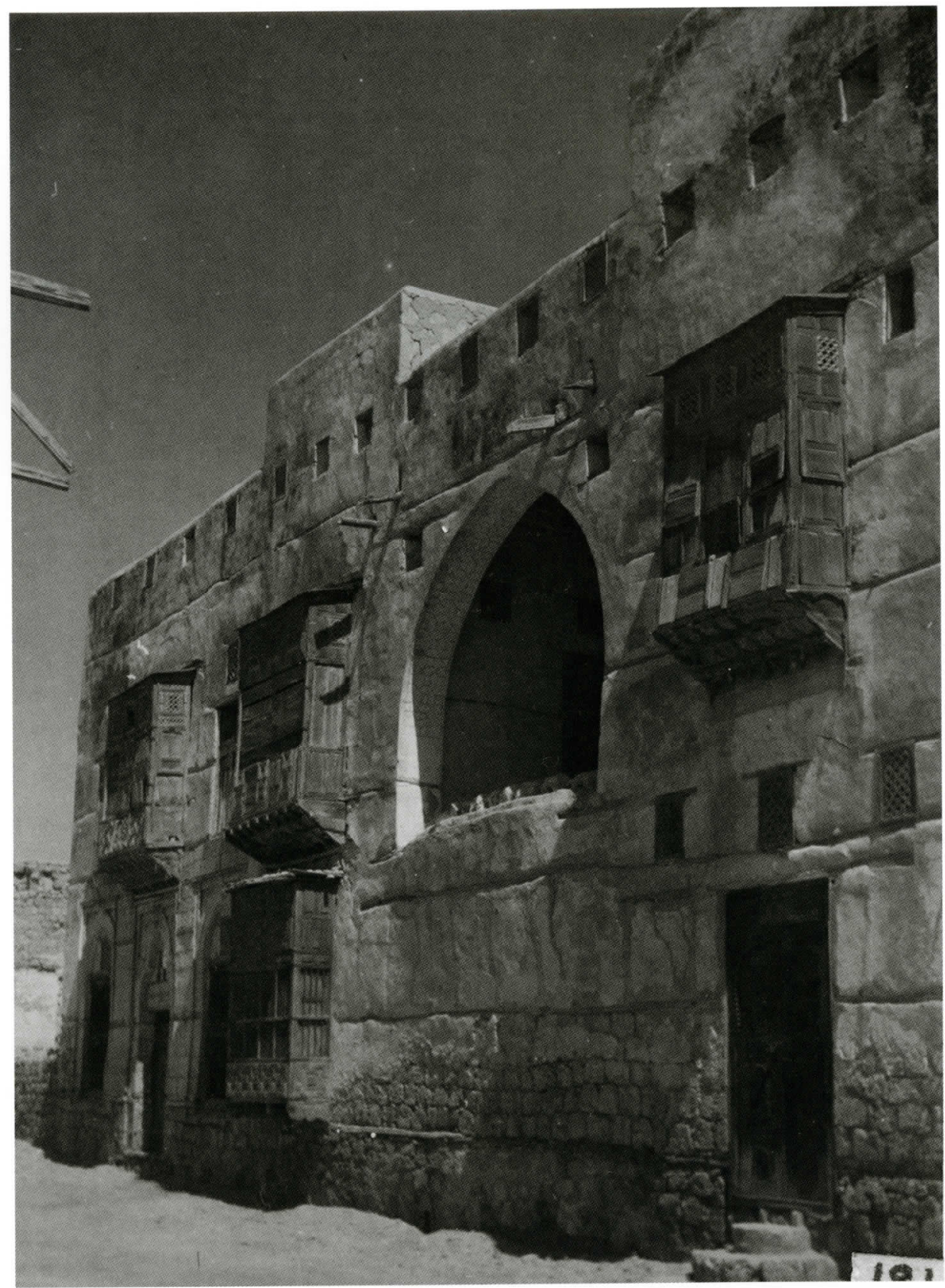

ish and Egyptian governance as "al-Turkiyya," or the Turkish era, a label that does not acknowledge any major difference between these two groups of outside rulers. ${ }^{12}$

It is also notable that this architectural periodization scheme only obliquely references the British imprint on Suakin's building. ${ }^{13}$ Rather, Greenlaw saw Egyptian architectural modes as the vehicle by which Europeanizing forms entered the island. This view, which conflates Western influence with Egypt, stemmed from the nature of Britain's relationship to Sudan, which was one of "triangulated conquest," as the historian Eve Trout Powell has argued (2003:5). Initially, the British engaged in Sudan as an extension of their activities in Egypt, which came under formal British rule in 1882. Their stake in Sudan escalated as a response to the Mahdist revolt, a powerful local anti-colonial movement that was halted by Colonel H.H. Kitchener at the famous Battle of Omdurman in 1898. This battle paved the way for British rule, which was then consolidated under the title of the Anglo-Egyptian Condominium that endured until 1956. However, this joint title signified Britain's power over Egypt rather than a shared and equal rule of Sudan. Essentially, the divisions between the historical periods of Suakin's history were hardly clear-cut. Turkish rule was tied up with Egyptian rule, which was tied up with British rule. For this reason, these temporal markers served as uncommonly inefficient historical signposts around which to orient an architectural chronology.

Furthermore, it was difficult to assimilate the houses, very few of which dated to a single period, but were rather built and then rebuilt over time, to the clean temporal contours of this developmental scheme that Greenlaw clung to tightly. ${ }^{14}$ As an example of this temporal messiness, Greenlaw classified Bayt Khurshid Effendi, a sprawling house located directly on the water, as the second earliest house in the city and a prime example of the original 


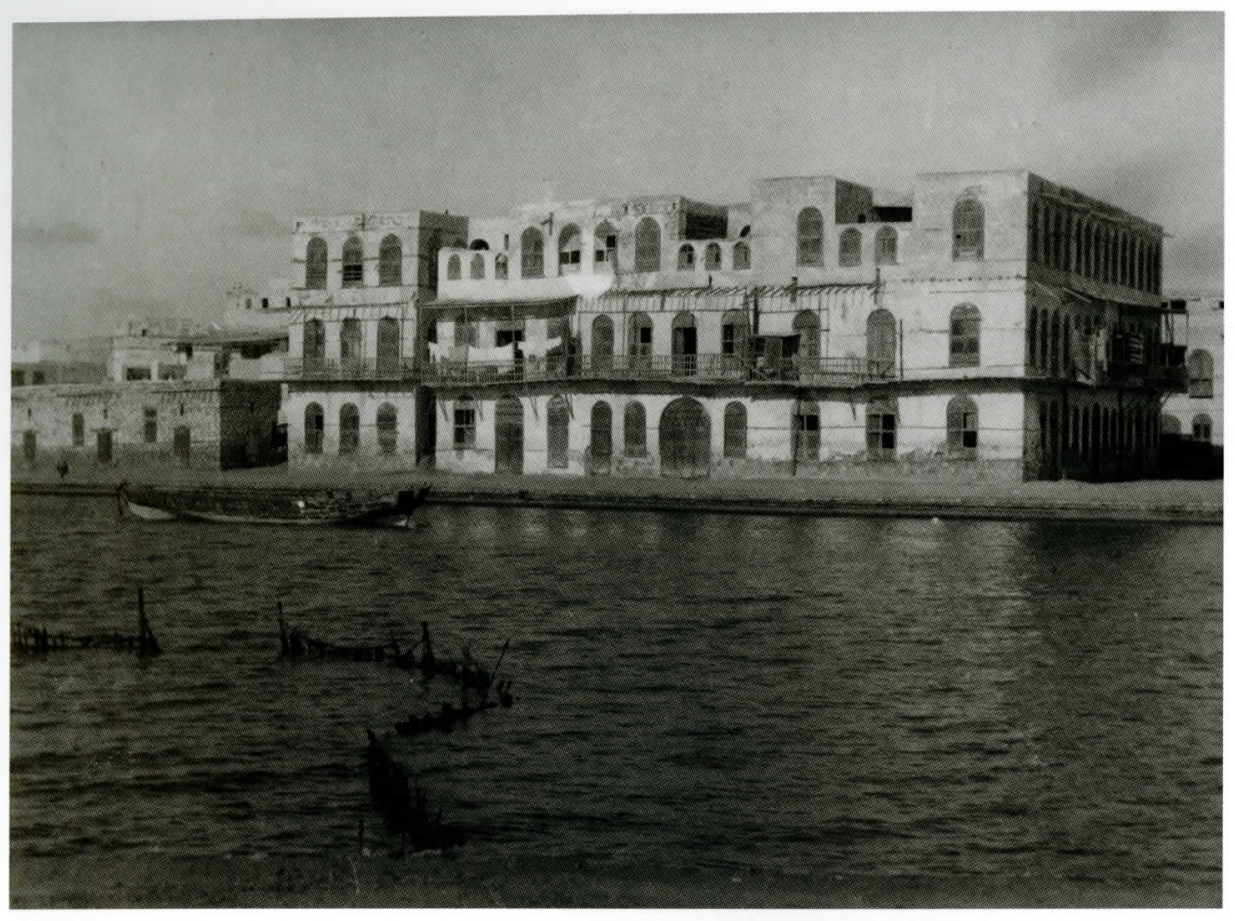

8 "Egyptian-style" houses, Suakin, Sudan GREENLAW, 1945-51. REPRODUCED COURTESY OF THE GREENLAW ARCHIVE, GRE P130.01B, SARS, LONDON.

According to the staged model of architectural development that Greenlaw adhered to, the Egyptian style was characterized by the use of open balconies, rather than projecting windows, and a blockier, less refined type of construction.

9 Drawing, Bayt Khurshid Effendi, Suakin, Sudan GREENLAW 1995:25

In his rendering of this house, which Greenlaw believed to have been the second earliest in the city, he selectively edited the space around the building, omitting the later National Bank of Egypt building, which loomed over the earlier structure. As comparison, see Figures 6, 10, and 11.

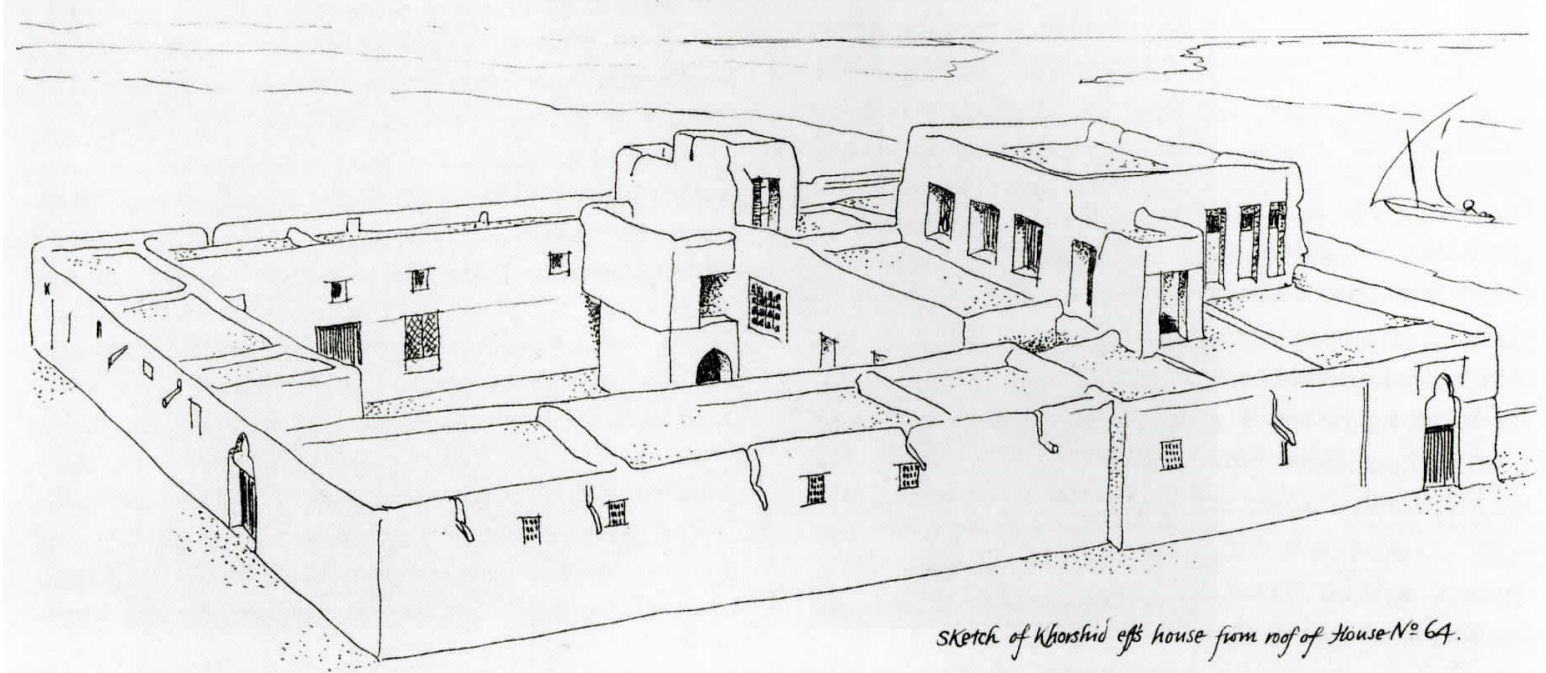

type, thereby freezing the building into this exclusive foundational group. ${ }^{15}$ Although he acknowledged once in passing that the foundation of the house may have been the only part of the building attributable to this initial moment, through the rest of the text, Greenlaw held firmly to the early assignment (1995:13). This was notwithstanding the fact that this house had been identified by at least one other well-known observer before him as the product of multiple stages of rebuilding into the modern era. ${ }^{16}$ Moreover, Bayt Khurshid Effendi was a rare example of a house that was still inhabited and intact up until 1964 (Phillips forthcoming). So it was truly a progressive and living structure, one of the few in the city at that time. Even so, Greenlaw struggled to render this building as a pure and static exemplar of Suakin's initial type.
Before turning to the images of Bayt Khurshid Effendi, it is necessary to explain Greenlaw's use of photographs. Beginning in 1945 or 1946 to 1951, when he left Sudan, Greenlaw used his intermittent teaching releases from Khartoum to document Suakin's architecture (Hinkel 1992:223). However, it was only after he returned to England that he turned to the formal production, finalization, and then publication of his drawings. ${ }^{17}$ Although he visited Suakin for two brief trips in 1973 and 1974 to recheck drawings for the book, there was a gap of thirty years between his first visits and the appearance of the publication (Greenlaw 1995:7). ${ }^{18}$ For that reason, photographs, as well as his sketches and notes, mediated his memory of the structures that he was depicting as he prepared his final drawings. Thus the two types of renderings, 


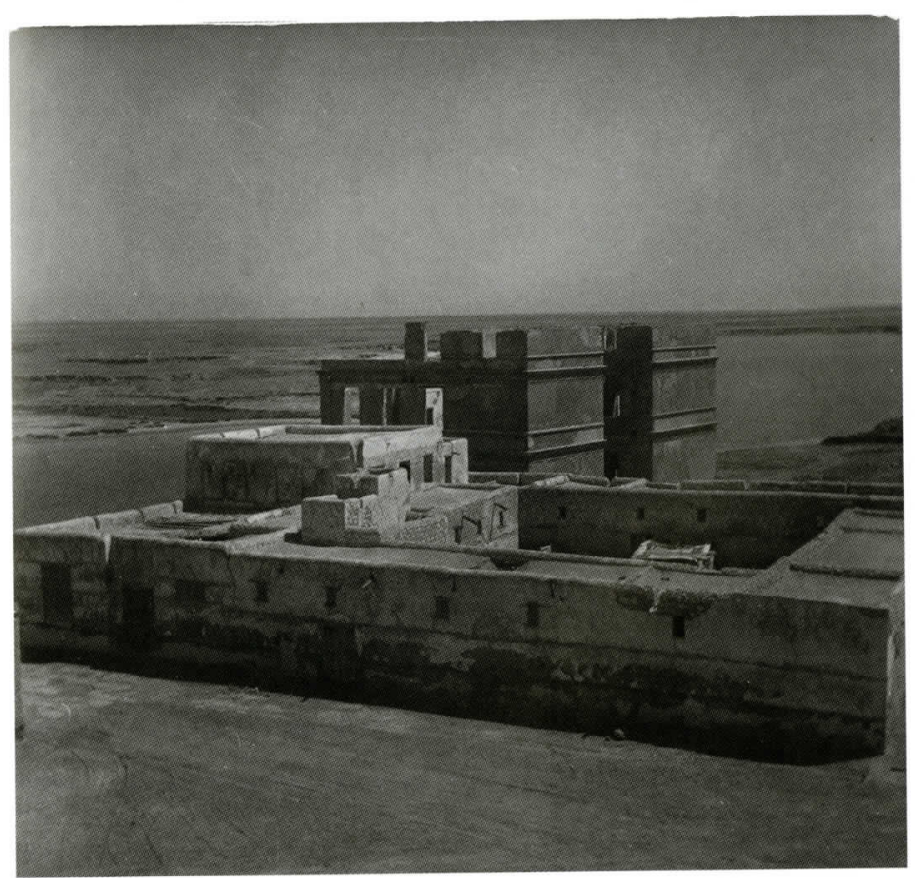

10 Bayt Khurshid Effendi from the northwest, with the National Bank of Egypt in the background, Suakin, Sudan

GREENLAW, 1945-51. REPRODUCED COURTESY OF THE GREENLAW ARCHIVE, GRE P157.02, SARS, LONDON.

The early-twentieth-century National Bank of Egypt building overshadowed Bayt Khurshid Effendi to the extent that it was difficult to photograph the earlier house without capturing the later one in the shot. Greenlaw found the Bank building to be an eyesore on Suakin's landscape and eradicated its presence from all of his drawings.

photographs and drawings, must be read together. The resources provided by the Greenlaw Archive, which includes over 1000 photographs and drawings from the artist's collection and is held by the Sudan Archaeological Research Society (SARS) and housed at the British Museum, have made such an inquiry possible. ${ }^{19}$

In order to deliver Bayt Khurshid Effendi to the idealized earliest era of Suakin's architectural development, but without acknowledging its continuing life, his published drawing of the house featured in Figure 9 shows it isolated from all other structures in the city. And it is clear that his value-laden judgments about the relative merits of Suakin's buildings oriented his selective process of editing the space around the house. As pictured in Figure 10, which shows Bayt Khurshid Effendi from the opposite angle, Greenlaw erased the National Bank of Egypt building from the older house's surroundings. The artist considered this later building, which was constructed directly adjacent to the residence's southern façade in the early twentieth century, to be the worst possible example of the Egyptian style that he so disfavored. Elsewhere, he called it "completely out-of-keeping with everything around it ... a large, pompous Neo-Classic affair, straight from Cairo or Europe, the outside of which was rendered in grey cement" with "little to commend it architecturally" (1995:84). By referring to the immediate backdrop of the Bank building, these comments point directly to Bayt Khurshid

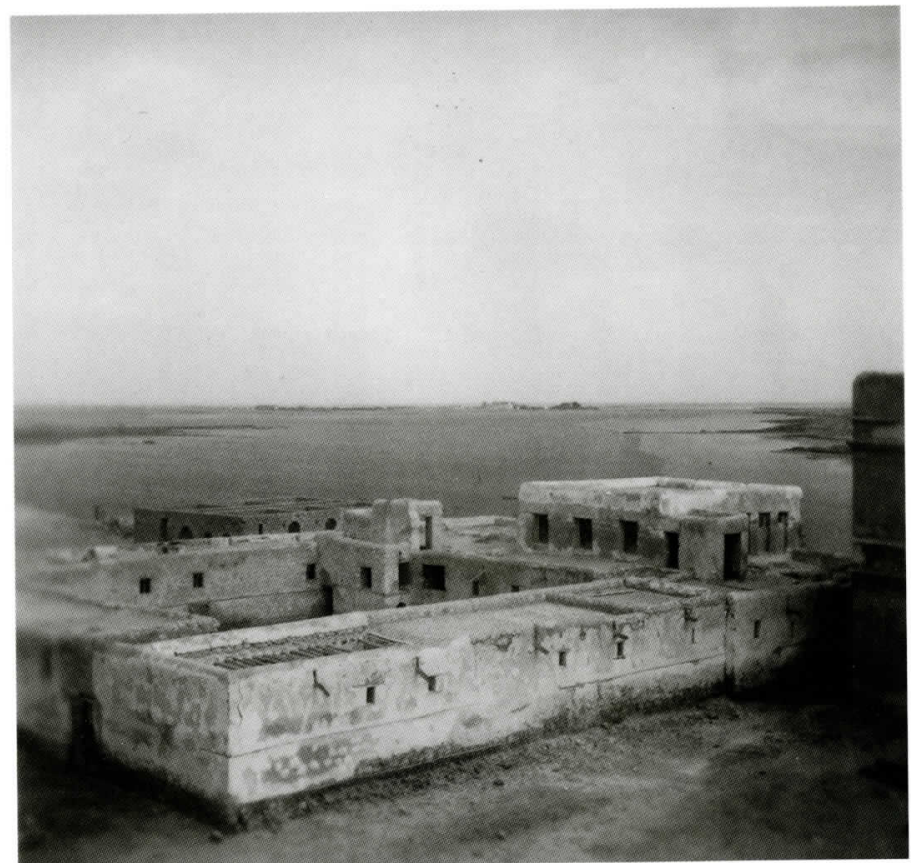

11 Bayt Khurshid Effendi, with the National Bank of Egypt visible, taken from the southwest from the roof of a neighboring house, Suakin, Sudan GREENLAW, 1945-51. REPRODUCED COURTESY OF THE GREENLAW ARCHIVE, GRE P099.01, SARS, LONDON.

This photograph shows how difficult it was to get a shot of Bayt Khurshid Effendi without including traces of the later National Bank building, which appears on the right edge.

Effendi as a key site. ${ }^{20}$ Additionally, they reveal that Greenlaw's interest in dialing time back to a past moment was not passive, but rather entailed an active process of removing a significant eyesore from the visual plane of the earlier building, which he believed to be one of the city's architectural gems.

Two alternate photographs taken from the southwest (Figs. 6,11 ) show that it was almost impossible to find an angle from which to see Bayt Khurshid Effendi without including part of its large looming neighbor. Although Figure 6 managed to excise the mass of the Bank effectively out of the viewfinder, its long dark shadow looms over the edge of the picture. Indeed, the two buildings were tied together visually and spatially in Suakin's twentieth-century urban fabric such that Greenlaw was unable to simply erase the cumbersome later addition. Rather, his retrospective goal required the construction of a new viewing stance composed of multiple superimposed vistas in order to bring out the house's major details, while carefully excising the Bank's intrusion. In particular, in Figure 9 he rescued the characteristic trilobed door hood on the house's southern façade from its occlusion under the later building's shadow, despite the fact that this detail was invisible from any angle (except from directly in front of the door) because of the Bank's tight enclosure. Moreover, Figures 6 and 11 reveal that Greenlaw's process of selective framing, which is crystallized in his published drawing, began 


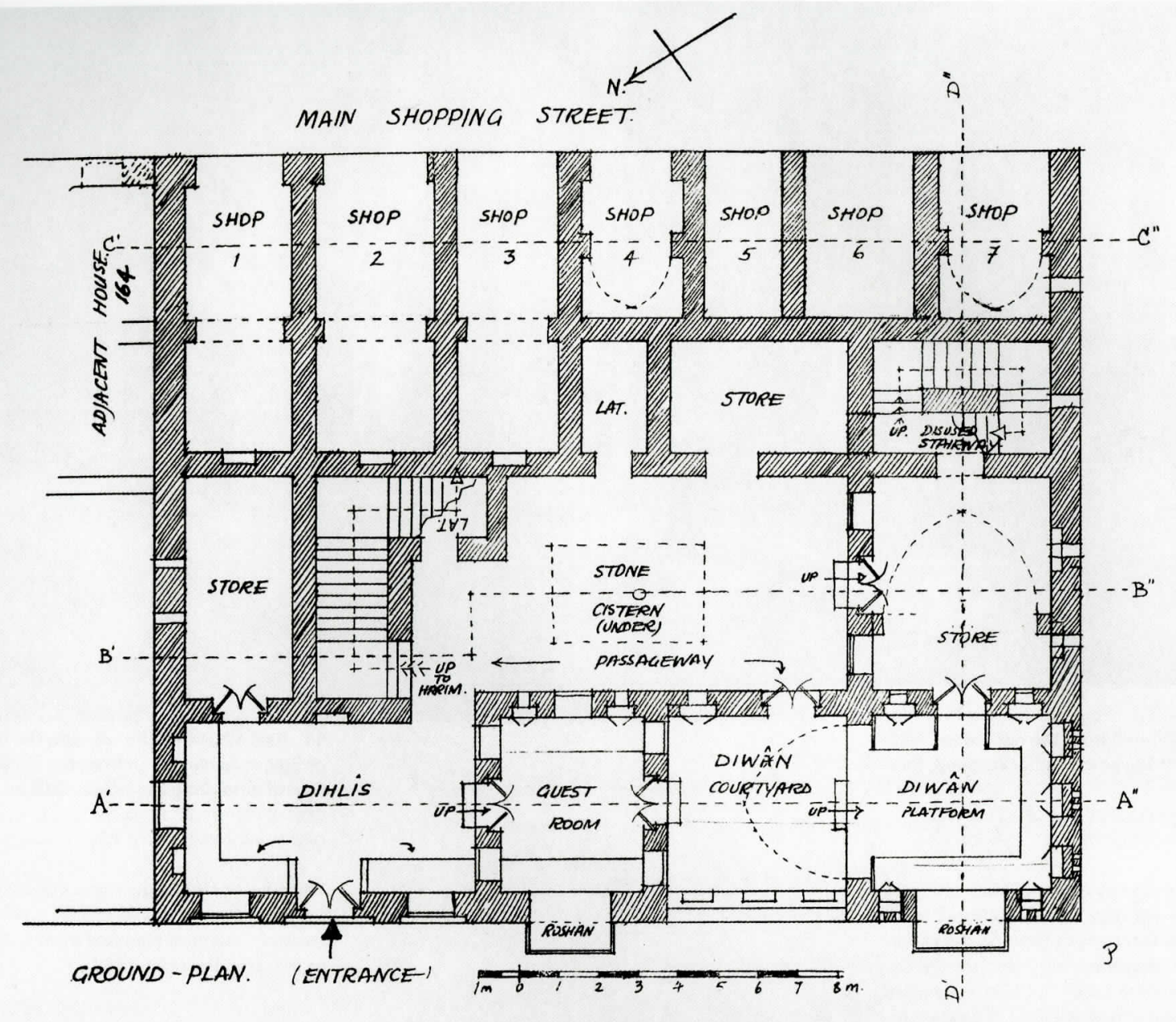

through the lens of his camera on site rather than through the more malleable medium of ink on paper in his studio. Indeed, his architectural photographs may not be considered transparent documents, but, like his drawings, photographs were also subject to his corrective eye.

With the remains of the Bank still lurking over its ruins, Bayt Khurshid Effendi is now destined to be the centerpiece of the city's contemporary reconstruction scheme. The current master plan for Suakin dictates that the house be rebuilt to serve as the future archaeological museum, which would represent a new stage in the building's continuing life. Greenlaw's images of this treasured house illustrate some of the artist's temporal struggles with rendering buildings in a city that was rapidly deteriorating, but had also moved far beyond the moment of its perceived highpoint. Indeed, the urban fabric of Suakin was progressive and its historical layers were tightly interlaced into the modern era, making this project of selective viewing and representation a difficult one. Here, I part ways with Hinkel, who depicted Greenlaw's documentary project as marred by inaccuracy. Greenlaw's burden was not only one of overlooked measurements and inconsistent scales, but rather a struggle with Suakin's hybrid state in the 1940s and 1950s, as it was marked by significant decay, but also the remnants of its modern accretion.
12 Plan, Bayt Shinawi Bey, Suakin, Sudan
GREENLAW 1995:32

In his plan, Greenlaw located the diwan's rawshan in its original place in the lower right corner, despite the fact that the projecting window had been removed and replaced with a door in order to facilitate the room's transformation into a museum.

\section{PRESERVING LOCAL HERITAGE: BAYT SHINAWI BEY}

After Bayt Khurshid Effendi, Greenlaw ranked Bayt Shinawi Bey as the third oldest house in the city and an impressive example of the Turkish style, the second phase of Suakin's architectural development (Greenlaw 1995:22). ${ }^{21}$ This large multistory building with shops built into its ground-level eastern façade was located in the center of the city. Like Bayt Khurshid Effendi, Bayt Shinawi Bey posed chronological challenges to Greenlaw's staged classification scheme, only fitting into the favored earlier Turkish category with great difficulty. Indeed, as Greenlaw was aware, the owners of the house were the renowned entrepreneurs of late-nineteenth-century Suakin, Mustafa Shinawi Bey and his ambitious son, Muhammad, who was the head of the local council, or majlis, and an active patron of architecture in the city (Miran 2009:305, n. 26) The family was from al-Mans- 


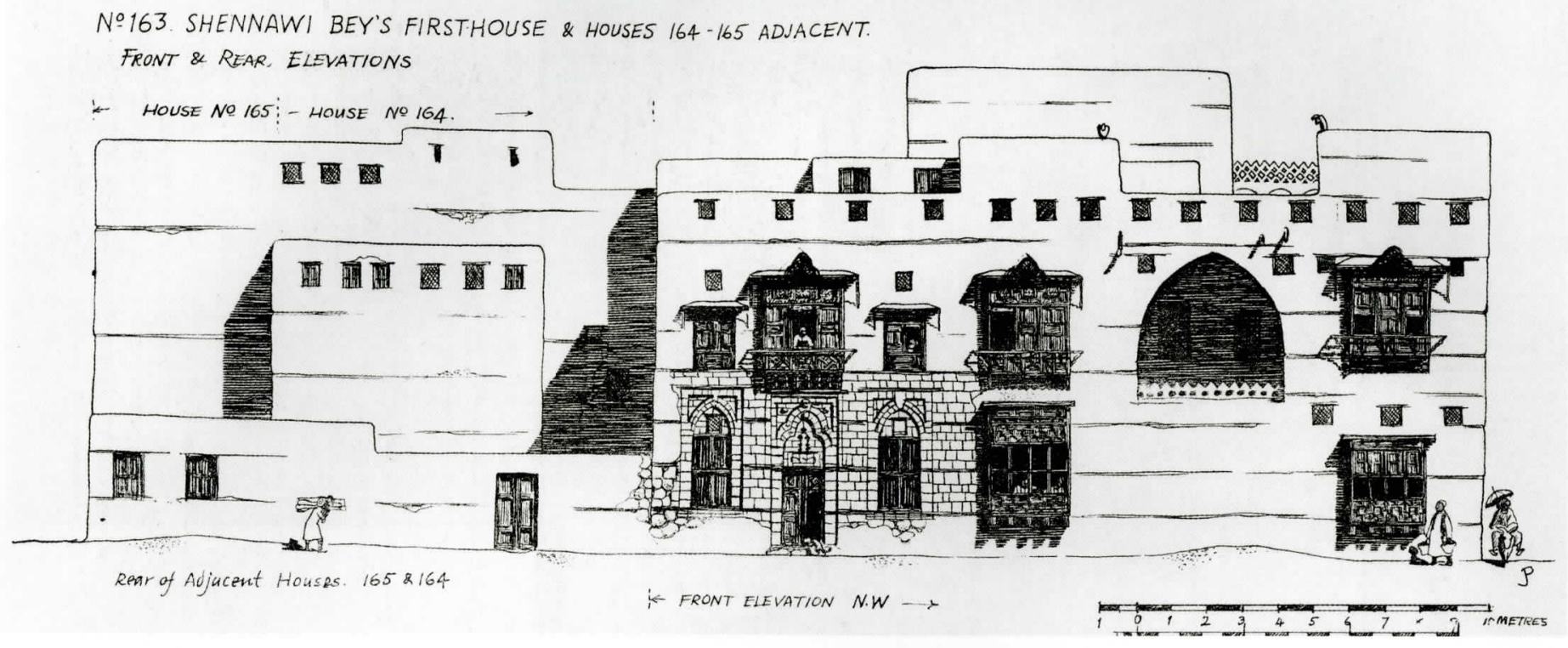

13 Western elevation, Bayt Shinawi Bey, Suakin, Sudan GREENLAW 1995:30

In the elevation, Greenlaw returned the house's western façade to its earlier state by reinstating the rawshan to its original place, thereby erasing the changes that were effected when the house hosted a museum briefly during the 1940s.

ura in the Egyptian delta region, so the assigned status of their house as early "Turkish" rather than nineteenth-century "Egyptian" was a shaky one (Serjeant 1977:205). Moreover, in his text, Greenlaw was never able to reconcile the fact that Shinawi Bey's second house, which he called the "new house of Shinawi Bey," and the mosque and wikala, or caravanserai, which Muhammad built on the mainland in 1881, appeared in the same publication under the label of late-nineteenth-century Egyptian-style buildings. So, again this key exemplar of the city's architectural peak was marked by its chronological unwieldiness within the developmental scheme offered by Greenlaw. Indeed, Greenlaw's discomfort with this assignment appeared fleetingly, when he admitted that some decorative elements of this house probably dated to the late nineteenth century (1995:60).

Moreover, like Bayt Khurshid Effendi, Bayt Shinawi Bey was an active structure, despite the fact that it was uninhabited during the middle of the twentieth century, when Greenlaw viewed it. ${ }^{22}$ Rather, the house was repurposed to host a museum in its diwan for a short period of time during the 1940s. This local museological effort represents the functional flexibility of Suakin's buildings after the city's heyday. As another example, in 1935, a Suakinese merchant named Muhammad al-Sayyid alBarbari offered two of his houses to the British administration as a "museum place," but with the caveat that he could take them back within twenty-five years provided he reimburse the expenses of the repair. ${ }^{23}$ The proposal was not accepted (Hinkel 1992:221). Regardless, it is clear that the desire to preserve and display Suakin's local heritage was not simply an imported colonial concern. As the city fell to ruin, some of its prominent residents struggled to hold on to its distinctive architectural tradition and famous past.

In accordance with the norms of Suakin's houses, the groundfloor diwan of Bayt Shinawi Bey was originally outfitted with a rawshan that extended the seating area of the room into the street, while also allowing rays of light and fresh breezes to enter the room through its grills. In order to accommodate the new function of public exhibition, this rawshan was then removed and replaced by a door, which facilitated direct entry into the museum space (Greenlaw 1995:29). This structural transformation is visible in Greenlaw's photograph (Fig. 7), where the outline of the previous window's wide opening may be discerned around the frames of the newer door.

In both the published plan of the house and its western elevation, Greenlaw reinstated the rawshan to its original location rather than featuring the newer door (Figs. 12-13). By rendering the rawshan in place of the door, Greenlaw's drawings erased the structural traces of this later museum, returning the house to its original function. He maintained this temporal outlook in his drawing of the interior of the diwan (Fig. 14), where the rawshan appeared in its original position and the museum objects on display were omitted. Rather, he rendered the room as a classic reception space with the traditional accessories that one would expect to find: a water pipe, a small table, and a pitcher. ${ }^{24}$ In his text, Greenlaw acknowledged this private museum only in passing, by mentioning that a doorway had replaced the rawshan when the diwan "was briefly turned into a museum in the 1940s"(1995:29). His drawings, on the other hand, completely erased the effort from the city's history and the house's architectural record.

Again, these particular choices in representation show Greenlaw's inherent struggle with the continuing lives of Suakin's buildings, some of which were physically altered to serve new purposes after the commercial demise of the port. But the case of Shinawi Bey's house museum is more complex than the previous 


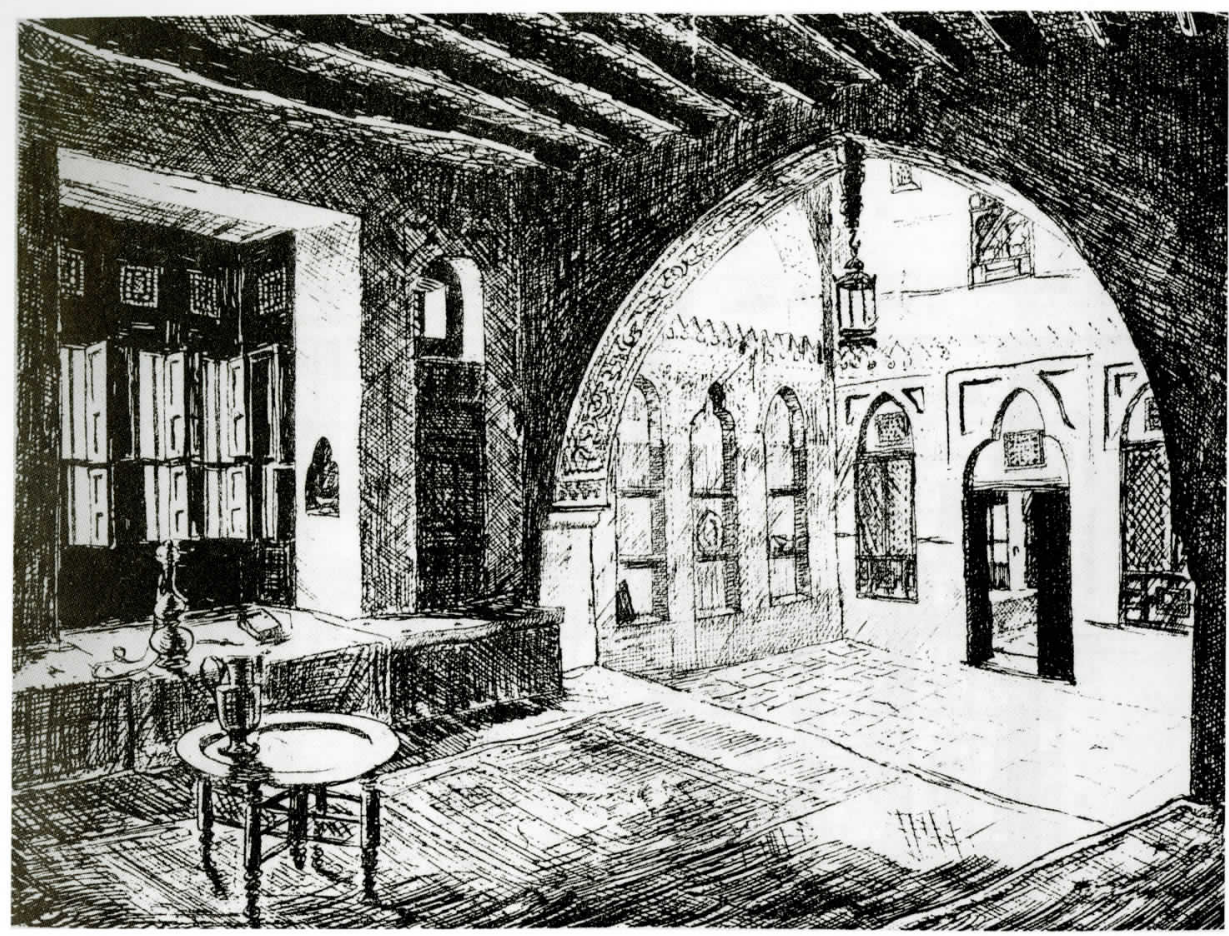

(this page)

14 Diwan, Bayt Shinawi Bey, Suakin, Sudan

GREENLAW 1995:31

Greenlaw's rendering of the diwan turned museum eradicated all traces of the room's display, as well as the transformation of the rawshan into a door. Rather, he returned the room to its original function of reception.

one of Bayt Khurshid Effendi because it entails issues of heritage, architectural preservation, and the politics of display. It should be noted that Greenlaw was the first to undertake a full visual study of the city of Suakin, but he was not the first to have an interest in its architectural legacy.

While 1909 was a key year for Suakin with the opening of Port Sudan, it did not mark the immediate and sudden end of merchant operations at the older port. In fact, trade continued in Suakin until the 1920s, when the National Bank of Egypt and the Eastern Telegraph office closed (Roden 1970:9, 14). But rather than shutting down abruptly, the port continued to serve the pilgrimage. ${ }^{25}$ The city's remaining, albeit largely diminished, economic activity then shifted to the adjacent mainland, called the Geyf. As early as 1926, British officials from Port Sudan began to discuss the preservation of Suakin's buildings as a public safety concern (Hinkel 1992:221). By the 1930s, international voices called to have Suakin preserved as an open-air museum, thereby compelling the British administration to explore possibilities for its preservation. However, insufficient funds and the complicated logistics of conducting repairs on private houses hindered the development of any comprehensive scheme (ibid., pp. 221-22). Since the 1950s, local and international figures have exerted pressure on UNESCO to adopt it as a World Heritage Site, but it has only made the tentative list (Hansen 1973, Mallinson 2010, Salim 1997). As noted above, the National Corporation for Antiquities and Museums of Sudan has escalated these efforts recently with international support.

At each stage of considering Suakin's possible preservation, artists, architects, and heritage specialists have produced a new set of visual documents of the city's architecture to make their cases (Matthews 1953; Hansen 1973; Hinkel 1992; Salim 1997). For that reason, preservation and heritage issues must be considered in tandem with those of architectural renderings. The latter have been used to bolster the former and, in the case of Suakin, the two processes have almost always been intertwined. In fact, in 1955, one of the first illustrated articles about Suakin's architecture appeared with a plea for outside intervention (Matthews $1955: 100,111)$. It is also worthy of note that Greenlaw eventually became disillusioned with the idea of preserving Suakin. In 1974, he advocated to UNESCO that the entire city should be razed and rebuilt from the ground up (Hinkel 1992:224, Clark 1977:48). This stance exemplifies his inherent difficulty in coping with the observed state of the city's buildings because they did not possess the purity and temporal uniformity of the specimens that he had created on his drawing board.

But even so, Greenlaw held convictions about what constituted legitimate architectural preservation. Although they were unarticulated in his text, these ideas come into focus when we look to his treatment of the Muhafaza building, which serves as a vital counterpoint to that of Bayt Shinawi Bey just discussed. Like Bayt Shinawi Bey, the Muhafaza building housed a local museum, but one founded by E.O. Springfield, the British Commissioner of Port Sudan, in 1938. It is quite remarkable that Suakin, which was depopulated and rapidly falling into ruin, hosted two museums during the 1940s. These efforts reveal that the city's residents and the colonial administration perceived the fleeting heritage of Suakin as extremely precious and worthy of preservation. However, the local and colonial responses to the past were quite different, as will be represented below.

The Muhafaza building had taken its two-story shape in the 1860s under the first Egyptian governor Ahmad Mumtaz Pasha and then became the local base for the colonial administration in 1884, when the British arrived in Suakin to respond to the Mahdist uprising. ${ }^{26}$ Characteristic of this era of building, it had many foreign features, such as a triangular pediment above its 

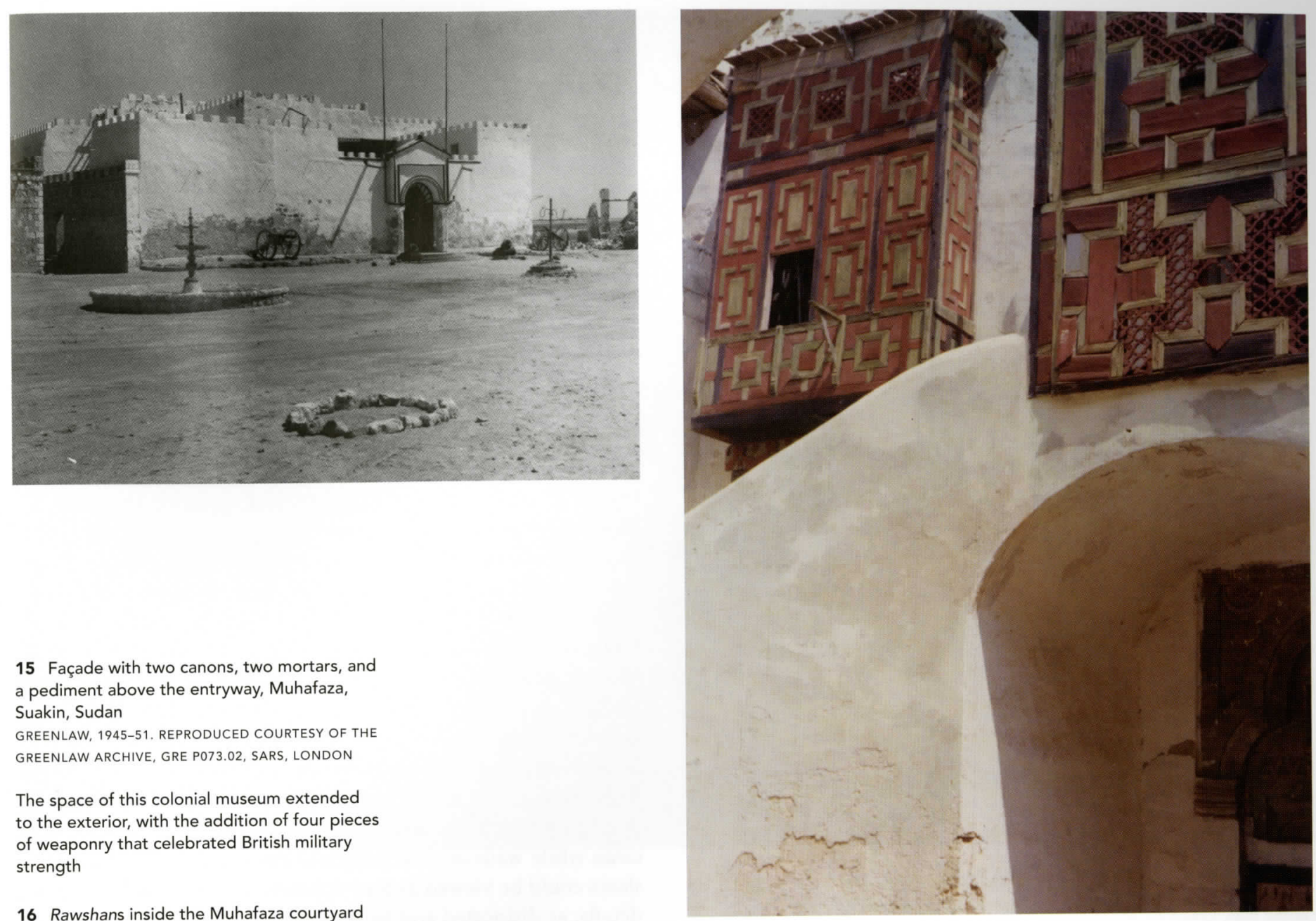

15 Façade with two canons, two mortars, and a pediment above the entryway, Muhafaza,

Suakin, Sudan

GREENLAW, 1945-51, REPRODUCED COURTESY OF THE GREENLAW ARCHIVE, GRE P073.02, SARS, LONDON

The space of this colonial museum extended to the exterior, with the addition of four pieces of weaponry that celebrated British military strength

16 Rawshans inside the Muhafaza courtyard with a view of the carved stone door hood below, Suakin, Sudan

GREENLAW, 1973 OR 1974. REPRO. DUCED COURTESY OF THE GREENLAW ARCHIVE, GRE P147.03, SARS, LONDON

In the 1930s and 1940s, various architectural salvage pieces were removed from their original settings and installed in the Muhafaza Museum. For instance, four rawshans were salvaged from collapsing houses and integrated into the building's courtyard, along with a carved door hood from a mosque, which is visible in the lower right corner.

17 Rawshans, exterior of the Muhafaza, Suakin, Sudan GREENLAW, 1945-51. REPRODUCED COURTESY OF THE GREENLAW ARCHIVE, GREP007.02, SARS, LONDON

When houses were demolished or collapsed, some of the finer pieces of woodwork were saved by the local administration and then reinstalled in the Muhafaza building, such as these two wooden projecting windows, or rawshans. Note the similarities between the Muhafaza's installation and Greenlaw's dislocated rendering of the two rawshans that appears in Figure 5.

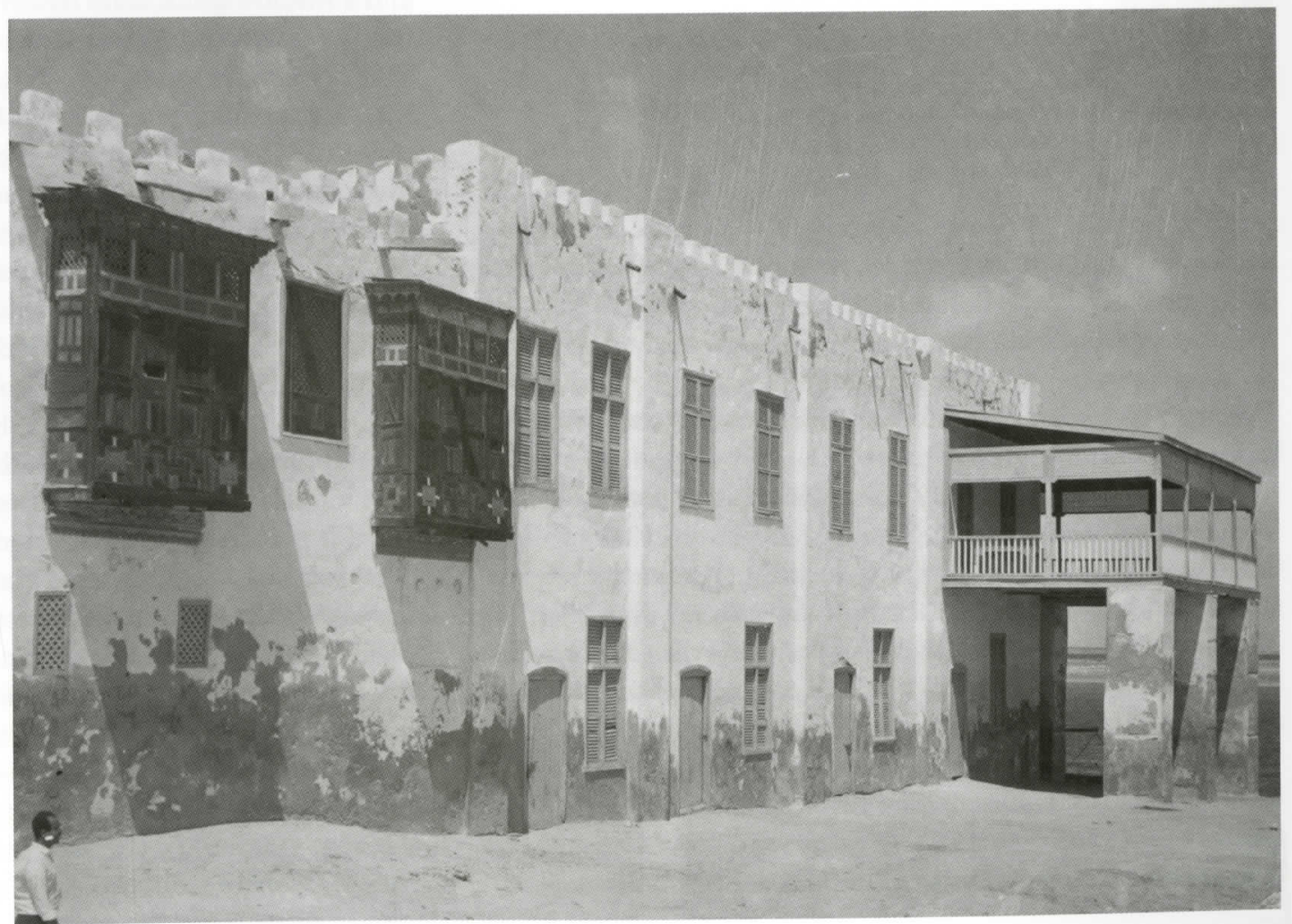


EGYPTIAN STYLE BUILDINGS

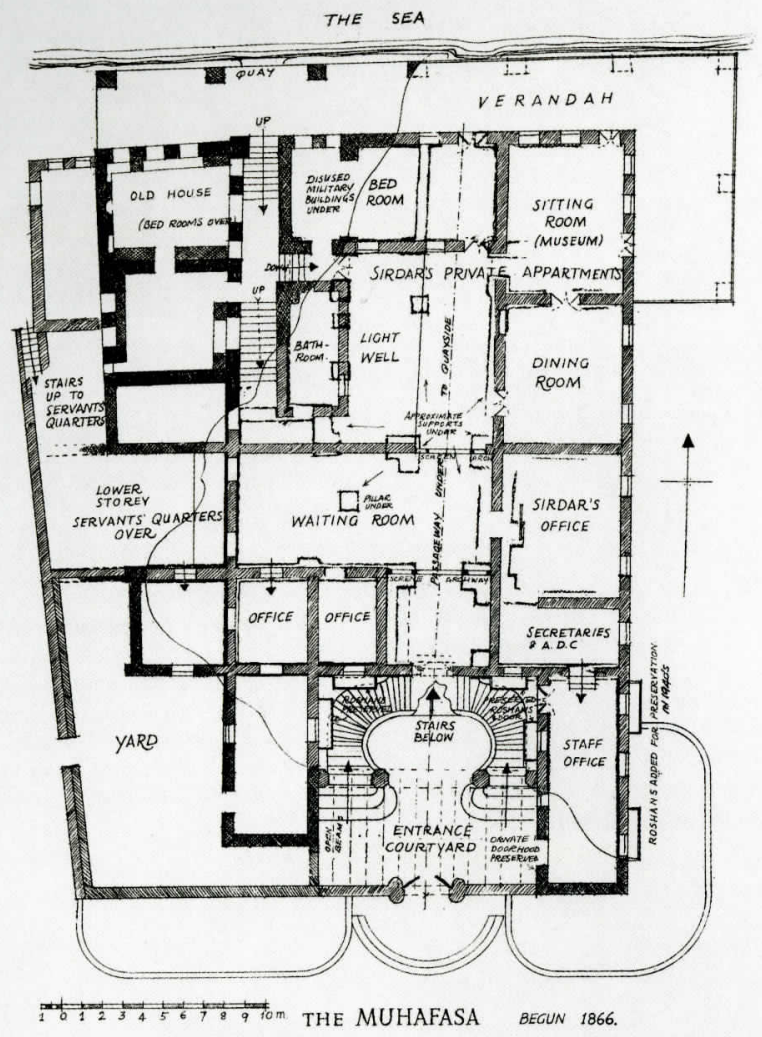

18 Plan, Muhafaza, Suakin, Sudan

GREENLAW 1995:74

In the plan, Greenlaw acknowledged the additions and amendments made to the building in the 1930s and 1940s when it was turned into a museum as legitimate transformations, by marking and labelling the newly added rawshans, the carved door hood, and the transformed exhibition room in the north. This approach is much different than the one that he used for his drawings of the house museum of Shinawi Bey, where he returned the building to its original domestic function, thereby erasing any trace of its museum.

entrance (Fig. 15) and a double winding staircase inside its entry vestibule. Despite these elements, which Greenlaw detested, and its late-nineteenth-century date, he included the building in his book as an example of the transition between the Turkish and Egyptian styles, which he believed to be more worthy of treatment than the outright Egyptian.

The museum's collection is relevant because it contained many architectural salvage pieces. But it also treated local culture in its main exhibition space, which was located in the northeast corner of the building. For instance, it featured an array of weaponry of the local Beja people, such as spears, various types of knives, and a shield made of hide (Hinkel 1992:68, 258). More artifacts could be found in the storage area, which comprised selected visual documents of the city's history, a painted wooden cot for a child, a dervish's robe, and pieces of salvaged architectural decoration, such as cupboards, part of a rawshan, and carved plaster fragments. ${ }^{27}$ Additionally, the institution served as a monument to colonial interests through the display of local British military memorabilia, such as the so-called dining room of Kitchener and four British cannons and mortars that were displayed prominently in front of the building, as visible in Figure 15 (Hinkel 1992:221). ${ }^{28}$ The juxtaposition of Beja weapons with the celebration of British military success in the region would have provided a poignant visual opposition. In particular, the memory of Kitchener would have reminded visitors of the violent confrontation at Omdurman and the ensuing fall of the Mahdists, while the Beja weapons would have recalled local participation in the same anti-colonial movement under the Suakinese leader Osman Digna.

Moreover, the museum building became a tableau for the reinstallation of architectural salvage pieces from collapsing houses around the city. Four rawshans (two of which can be seen in Figure 16), a large wooden carved panel, and a reused door were installed inside of the structure around the open-air courtyard (Greenlaw 1995:49, 126). ${ }^{29}$ A carved stone door hood, also visible in Figure 16, was relocated from a neighboring mosque to the building's ground floor. ${ }^{30}$ Two additional rawshans were added to the exterior (Fig. 17). With these salvaged pieces, the Muhafaza museum provided a safe space for the preservation of prized architectural elements, the very same elements that Greenlaw took pains to preserve in his drawings. In a brief note in his text, Greenlaw commended the commissioner for his efforts, which he understood as legitimate attempts at architectural preservation. Indeed, the reoutfitted Muhafaza mirrored the methods of display that he undertook in his drawings. Relocated to the clean white walls of their adopted home, the newly placed rawshans could be viewed as they appeared in Greenlaw's published details, as dislocated and isolated visual samples of a past mode of domestic fenestration to be appreciated for their decoration and form (Figs. 5, 17). Indeed, some pieces, such as a rawshan and a window grille, were rendered in his text labeled with their original location in addition to their new status as part of the Muhafaza collection. ${ }^{31}$

Greenlaw further confirmed his approval of the Muhafaza's preservation efforts with the notations on his plan of the building, which acknowledged these modern transformations as justifiable amendments to the building's original fabric (Fig. 18). Projecting rectangles marked the new positions occupied by the rawshans. Additionally, labels stating "sitting room (museum)," "roshans [sic] added for preservation," "ornate door-hood preserved," and "roshans [sic] added for preservation in the 1940s," affirmed these later interventions. These notable inclusions demonstrate that Greenlaw's interest was not only to freeze Suakin's history to a past moment in time, as he himself suggested. Rather, he had distinct ideas about what types of transformations to its architecture could be sanctioned. Whereas he erased the structural change that accompanied the establishment of the museum in Bayt Shinawi Bey, the colonial efforts at display and preservation of the Muhafaza museum, with their associated structural changes, were approved implicitly by their appearance on his plan.

It is clear that the museum at Bayt Shinawi Bey took a very different view on the preservation of Suakin's past and the exhibition of local culture. According to Hinkel, the display of the 


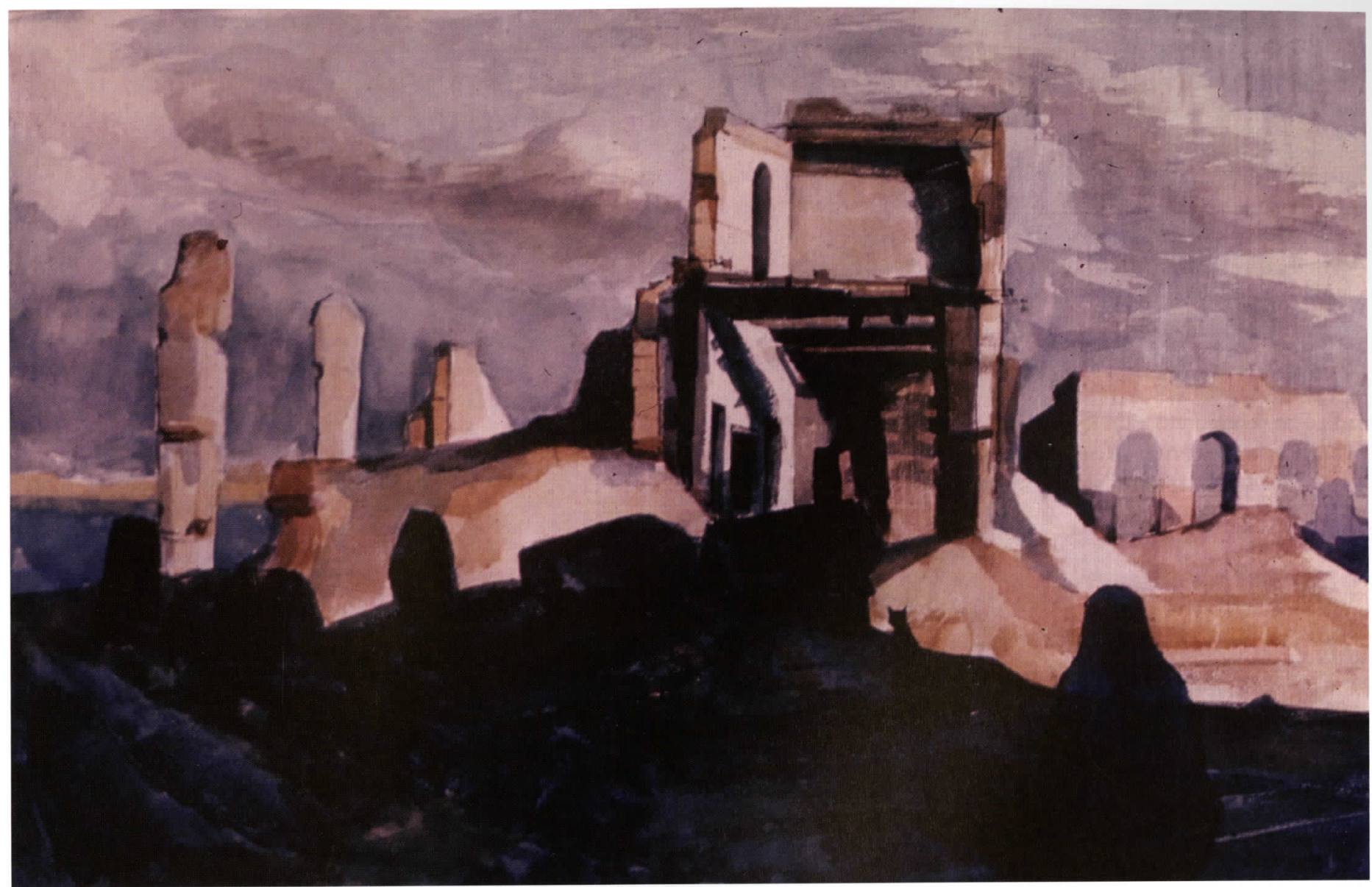

19 Ibrahim El Salahi

Ruins of Suakin, Sudan (late 1950s)

Watercolor; $52 \mathrm{~cm}(201 / 2 ")$

Collection of John J. McKelvey Jr.

(c) 2011 ARTISTS RIGHTS SOCIETY (ARS) NEW YORK/DACS, LONDON

two bent-wood rocking chairs, and a modern clock" (1992:241). Certainly one could argue that these various objects pointed to the cosmopolitan past and famous heritage of Suakin, but not in a manner that would be legible to all viewers. Presumably the seashells came directly from the city's shoreline, signifying Suakin's strategic coastal location with its illustrious economic past. In terms of the chairs, in Suakin, there was no need for freestanding furniture (except for perhaps the angareeb or traditional raised bed made of wood, leather, and rope) because raised benches were built into the rooms, as visible in Figure 14. However, chairs circulated around the twentieth-century British-dominated Indian Ocean, functioning as signifiers of wealth, modernity, and worldliness among the elite cosmopolitan class (Meier 2009:12-13, 15; Prestholdt 2008:36-37). In the same spirit, the modern clock was always prized as an icon of modernity in Africa and the Middle East. These clocks were rarely calibrated to the local time, but nevertheless were cherished objects of display that signified their value as commodities and technological innovations, rather than any adherence to Western norms of temporality (Prestholdt 2008:91, 96, 108). The stuffed fox was likely a local curiosity and prized possession of one of the local residents, perhaps Muhammad Shinawi Bey himself. Clearly, the museum at Bayt Shinawi Bey operated along principles of exhibition that diverged from Greenlaw's attempts at architectural preservation, as well as the ethnographically and architecturally
Whereas Greenlaw struggled to restore the decaying buildings of Suakin in his drawings, his former student Ibrahim El Salahi acknowledged the port city's contemporary state in his watercolor, which pictures the city in ruins.

circumscribed view of heritage on display at its colonial rival, the Muhafaza. Small wonder that Shinawi Bey's house museum, which celebrated modern innovations and Suakin's eclectic maritime identity, did not receive Greenlaw's fickle visual sanction.

\section{CONCLUSION: ANOTHER VIEW OF SUAKIN}

To conclude, it is appropriate to move beyond the covers of The Coral Buildings to look at a view of Suakin provided by another observer. In the late 1950s, Ibrahim El Salahi, Greenlaw's most renowned student, produced a watercolor of the city under the title The Ruins of Suakin (Fig. 19). It is no surprise that the site would have inspired El Salahi. Greenlaw brought his students from Khartoum to Suakin on his many trips during the 1940s and 1950s (Hale 1977:5). Alongside their teacher, his pupils visited each house and rendered the various spaces and decorative details (Clark 1977:47). In a 2002 interview, El Salahi claimed that Greenlaw's "way of seeing life had a great influence on" him and named his British mentor, along with Shafiq Shawqi and 
Osman Waqialla, as formative figures in his training. ${ }^{32}$

While this image could be understood as homage to his revered teacher, El Salahi's rendering of Suakin provides a starkly distinct perspective on the city. Unlike Greenlaw's heavily restored but selectively detailed monochromatic images of the city's architecture, El Salahi's port city appears through tectonic pieces of sculptural ruins, clods of steely grey earth, and isolated remnants of creamy white pillars. Whereas Greenlaw corrected the ruins and eradicated certain types of urban change, El Salahi saw a configuration of structural detritus, acknowledging that Suakin had become a new visual formulation of picturesque ruins. In his images, Greenlaw grappled with the effects of time on the city's fabric and struggled to represent the city at an arbitrary, yet coherently constructed moment in its past. On the other hand, El Salahi reveled in the city that he witnessed, a destroyed and crumbling subject on the brink of disappearance..$^{33}$
El Salahi's watercolor represents the continuing and visually potent life of Suakin's coral buildings after the port's heyday. Even today, Suakin is on the brink of a revival. And if proposed schemes take shape, its buildings will be repurposed once again and redefined for new audiences, extending the city's long and contested visual life.

NANCY $U_{M}$ is associate professor of art history at Binghamton University and Reviews Editor of the International Journal of Islamic Architecture. Her research treats visual and material culture and the built environment of the southern Arabian Peninsula, the Red Sea, and the Indian Ocean. Her book The Merchant Houses of Mocha: Trade and Architecture in an Indian Ocean Port was published by the University of Washington Press in 2009.nancyum@binghamton.edu

\section{Notes}

The author wishes to thank Michael Mallinson, who kindly shared unpublished material from the Suakin Project. Over many cups of tea in London and through countless emails, Jacke Phillips has been extremely generous with her recent findings from Suakin and her vast knowledge of the city. Derek Welsby of the Sudan Archaeological Research Society kindly made the Green law archive available to me in July 2010 and allowed me to feature images from the collection. The artist Ibrahim El Salahi graciously allowed me to reproduce his watercolor in this article.

1 However, the Geyf, the inland neighbor to the island of Suakin, is still inhabited and thriving as a port.

2 Greenlaw played a major role as an advocate of arts education in Sudan and other parts of Africa, including Nigeria. His illustrations fill many teaching manuals and official reports on Sudan's schools. See Anonymous 1950, Greenlaw 1966, Griffiths 1953:104105, Hodgkin 1994:11.

3 The plans for the Suakin Project are available at the website of Mallinson Architects and Engineers. Michael Mallinson, the British architect who undertook the renovation of the Sudan National Museum in Khartoum, spearheads the project (mallinsonae.com, Mallinson 2004, Mallinson et al. 2009).

4 Suakin's fate is hinged to the future of Sudan's oil reserves, the majority of which will be held by the newly created Republic of South Sudan. In fact, the whole coastal region was revitalized in the late 1990 s when President Bashir built a pipeline linking the southern oil fields to the Red Sea, at the newly constructed oil tanker terminal of Marsa Bashayir, located between Suakin and Port Sudan.

5 Originally, Greenlaw had intended to publish photographs in the book, but in the end did not, probably because of budgetary constraints. According to Clark, Greenlaw then decided to publish two additional volumes on Suakin after The Coral Buildings. The second one, provisionally entitled "The Vanished Buildings of Suakin" was to feature photographs of the city, including historical images and presumably the author's own shots. Neither book ever made it to press (Clark 1977:48, Hansen 1973:20).

6 Hinkel published his findings in 1992, more than twenty years after his first trip to Suakin, but he gave earlier lectures on the topic and produced an unpublished report entitled "Scheme for the Preservation and Maintenance of Suakin" in 1968 (Hansen 1973:i, Insoll 1998:83).
7 In a footnote, Greenlaw admitted that all of his measurements were off by $4 \%$ because he had relied upon the scale used in Jidda, which was not identical to that of Suakin (Greenlaw 1995:132, n. 17). Clearly, Hinkel found his measurements to be even more flawed.

8 However, because the criticism of Greenlaw's project has appeared in specialized archaeological reports rather than mainstream art historical or architectural sources, it is surprisingly unacknowledged in the scholarly reception of his work.

9 For instance, Matthews used Greenlaw's unpublished plans for his 1953 publication, but Greenlaw cited Matthews as a source in 1976. Hansen relied on Hinkel's 1968 field report and urged UNESCO to consider funding Greenlaw's publication, which had not yet found a publisher at that time (Hansen 1973:1, 20).

10 For some reason, Greenlaw chose the year 1860 as the beginning of the Egyptian style. This happens to be a fairly arbitrary year that predated the rule of the Egyptian Khedive in 1865 and the opening of the Suez Canal in 1869. Moreover, it is ironic that Greenlaw's chosen moment of Suakin's commercial heyday was the year 1900 , which by his own assessment was a time of architectural decline (Greenlaw 1995:22).

11 Recently, archaeologists have confirmed Greenlaw's dating of Bayt al-Basha to the sixteenth century, based on carbon-dated remains excavated at the site. The debate about single-story structures as the original Red Sea type continues today (King 1996:341, Hansen 1973:5, Mallinson et al. 2009:481).

12 It is important to identify that Greenlaw maintained a differential scale concerning the notion of foreign influence. For him, the city's architecture reached a high point under Turkish rule. He proposed that during this time building techniques and designs came from the Arabian Peninsula as a legitimate shaping factor. But, in the following period, those that came from Egypt and Europe were seen as unwelcome alien introductions. With its distinctive woodwork made of imported hardwood from Southeast Asia carved in designs that were reminiscent of both Turkish and Indian craftsmanship and its towering elevations resembling those of the Arabian Peninsula, the buildings of Suakin were difficult to cast in a single cultural frame. Rather than accepting these cultural complexities, Greenlaw chose to revere certain categories, such as Hijazi or Turkish, and reject others, such as Egyptian or European.

13 Greenlaw referred only once to "Anglo-Egyptian fashions" in a derogatory manner (1995:61).

14 This progressive aspect of Suakin's buildings has been effectively brought out by recent archaeological work (Mallinson 2010, Phillips forthcoming).

15 This house appears in his publication as "Beit Khorshid Effendi," house number 64 .

16 Bloss (1936:294) believed that the structure was built originally in the 1770 s. It should be noted that Greenlaw included Bloss's writings in his brief footnotes, so he was aware of the former's assessment.

17 Greenlaw was occupied with many projects after he left Sudan. He spent five years as "a wandering scholar visiting and studying in many religious institutions in the Middle East, Italy, France and England," eventually finding refuge with the Dominican Brothers of Provence in Sainte Baume, France (Greenlaw 1981:4). There, in 1953, he claimed to have had a transformative experience in which a visual manifestation of Christ appeared to him. This composite symbol consisting of spiral orbs bisected with a yin yang symbol, surrounded by several rounded outlines, became the basis of a theory of Creative Symbolism that he adhered to for the rest of his life. This theory involved an ecumenical Christian outlook that he used as a tool to teach basic art forms and concepts. He published numerous pamphlets on the topic in 1980 and 1981 and held some exhibitions in England. He was also posted in northern Nigeria as a teacher and wrote a text on how to teach art at the primary school level in the developing world. It should be noted that the teaching guide relied on many of the forms and shapes that he featured in his writings on Creative Symbolism, but without the Christian context. Moreover, hints of this spiritual orientation appear in the text of The Coral Buildings (Greenlaw 1966, 1995:132).

18 This long hiatus may be accounted for by the fact that he had a hard time securing a publisher and eventually ended up having it published privately (Hansen 1973:20).

19 While the archive is copious in its holdings, this preliminary study will sample only two houses that Greenlaw identified as the earliest and most important in the city, Bayt Khurshid Effendi and Bayt Shinawi Bey, as a starting point for the reassessment of Greenlaw's work.

20 He found the National Bank building to interfere in other picturesque views of the city. In another section of the text, he complained about how the street façade in front of two other earlier houses was defaced by its "ugly, grey cement-faced Neo-Classic bulk." In the 1930s, the Bank structure was used as a resthouse, but was then partially destroyed in 1947 (Greenlaw 1995:40, Bloss 1937:277, Hinkel 1992:233).

21 In The Coral Buildings, this name appears as 
"Shennawi Bey" and the house is number 163.

22 Presumably, at some point in the mid twentieth century, the family moved from the old house to the newer house, which was built in the late nineteenth century, across the street. However, by 1955, the new house also suffered from deterioration (Hinkel 1992:241, 243; Greenlaw 1995:81).

23 Al-Barbari was one of the few merchants who remained in Suakin long after most others had left. In 1933, he attempted to reinvigorate the failing local economy by setting up a cotton-dying factory in the town's prison, which was no longer being used. According to Roden's assessments, this initiative allowed Suakin's cotton imports to rise significantly from 1933 to 1935 , but was discontinued during World War II (Roden 1970:15, Bloss 1937:277).

24 The built-in niches in the entry vestibule to the room were not outfitted for the museum, but rather were a classic feature of Suakin's houses. They were used to display plates, metalware, and other treasured belongings of the household.

25 A new pilgrimage terminal was built in the area recently, thereby continuing the city's long-time role in conveyance of the pious.

26 At that time, the British added four brass plaques into the eastern wall of the building. Of the three that remain, one commemorates the year, 1884 , and the other two represent British military accessories, a shield, spears, and a gun. In 1978, the Sudan Antiquities Service proposed to make the Muhafaza a museum once again, which was rejected. Currently, the provincial government, the Red Sea state, is undertaking plans for restoration (Rhodes 2011:172; Hinkel 1992:257; Jacke Phillips, personal communication, July 26, 2010, London).

27 The museum was kept open until around 1948 , but some objects were still on view in 1953, when the archaeologist of East Africa H.N. Chittick recorded the remaining contents. $\mathrm{He}$ did not include two pieces that Greenlaw mentioned seeing there: a photograph of a local religious figure, Muhammad 'Uthman Taj al-Sir, and a circular table with three horse-shaped feet (Hinkel 1992:68, 258; Greenlaw 1995:67, 130).

28 Although it is not specified, I presume that this "dining room" would have included the furnishings and place settings that Kitchener used when Suakin served as his base for the campaign against the Mahdists.

29 In 1942, craftsmen were called from Jidda to install the woodwork. This fact demonstrates that there was no new building activity in Suakin at that time and that local architectural expertise had diminished (Roden 1970:16).

30 Greenlaw incorrectly identified the door hood as coming from an "unidentified house." It was actually taken from the Hanafi mosque, located across the square from the Muhafaza. Some photographs in Greenlaw's collection show it in its original position. Hinkel repeated this error of original attribution, which is surprising because he surveyed the Hanafi mosque carefully and oversaw renovations there in the 1960 s and 1970s (Greenlaw 1995:95, Hinkel 1992:257).

31 These included a rawshan from house number 220 and a piece of grilled woodwork from house number 86 (Greenlaw 1995:105, 126).

32 "Quelles philosophies pour les écoles? Entretien de Marie-Christine Eyéné avec Ibrahim El Salahi," May 1, 2002. http://www.africultures.com/php/index. php?nav $=$ article\&no=2225. Accessed May 27, 2011.

33 Another important view of Suakin is encapsulated in Hussein Shariffe's film Intiza 'al-Kahraman [The Dislocation of Amber] (1975), which was filmed in Suakin. While, like El Salahi, Shariffe captured a city in ruins, his film is inhabited by people, rather than devoid of human life.

\section{References cited}

Anonymous. 1950. Subul Kasb al-Aysh fi al-Sudan [Ways of Living in Sudan]. Khartoum: no publisher.

Bloss, J.F.E. 1936. "The Story of Suakin, parts 1 and 2." Sudan Notes and Records 19 (2):271-300.

1937. "The Story of Suakin, part 3." Sudan

Notes and Records 20 (2):247-80.

Clark, Isobel. 1977. "Greenlaw's Coral City." Sudanow (July):45-48.

Garlake, P.S. 1978. "Review of The Coral Buildings of Suakim [sic] (Boston, 1976)." Journal of African History 19 (2):305-306.

Greenlaw, Jean-Pierre. 1966. Drawing and Handiwork and Design: Year 1. London: Thomas Nelson and Sons.

1981. Discovery of the Form of Forms and

Creative Symbolism. Henley-on-Thames, England: no publisher.

1995. The Coral Buildings of Suakin: Islamic Architecture, Planning, Design and Domestic Arrangements in a Red Sea Port. London: Kegan Paul. Work originally published 1976 .

Griffiths, V.L. 1953. An Experiment in Education: An Account of the Attempts to Improve the Lower Stages of Boys' Education in the Moslem Anglo-Egyptian Sudan, 1930-1950. Suffolk: Richard Clay and Company.

Guha-Thakurta, Tapati. 2003. "The Compulsions of Visual Representation in Colonial India." In Traces of India: Photography, Architecture, and the Politics of Representation, 1850-1900, ed. M. Pelizzari, pp. 108-39. New Haven CT: Yale University Press.

2004. Monuments, Objects, Histories: Institutions of Art in Colonial and Postcolonial India. New York: Columbia University Press.

Hale, Sondra. 1977. "Review of The Coral Buildings of Suakin (Boston, 1976)." African Arts 10 (4):5-8.

Hansen, E. 1973. Preservation of Suakin, OctoberNovember 1972. Paris: UNESCO.

Hassan, Salah M. 1995. "Khartoum Connections: the Sudanese Story." In Seven Stories about Modern Art in Africa, ed. C. Deliss, pp. 102-125. London: Whitechapel Art Gallery.

Hinkel, Friedrich. 1992. The Archaeological Map of Sudan. Vol. 6. Berlin: Akademie Verlag.

Hodgkin, R.A. 1994. "A National Curriculum for the Northern Sudan: The Attempt by British and Sudanese Teachers at Bakht er Ruda to Reform Education in the Years Before Independence." Sudan Studies 15 (January):5-11.

Insoll, Timothy. 1998. "Review of The Coral Buildings of Suakin: Islamic Architecture, Planning, Design and Domestic Arrangements in a Red Sea Port (London, 1995)." African Archaeological Review 15 (1):81-83.

King, G.R.D. 1996. "Review of The Coral Buildings of Suakin: Islamic Architecture, Planning, Design and Domestic Arrangements in a Red Sea Port (London, 1995)." Bulletin of the School of Oriental and African Studies 59 (2):341-42.

Mallinson, Michael. 2004. "Suakin 2003/4." Sudan \& Nubia 8:90-94.

2010. Suakin Project-History and Research towards a New World Heritage Site. Unpublished report.

Mallinson, Michael, Laurence Smith, Colin Breen, Wes Forsythe, and Jacke Phillips. 2009. "Ottoman Suakin 1541-1865: Lost and Found." The Frontiers of the Ottoman World. Proceedings of the British Academy 156:469-92.

Matthews, Derek H. 1953. "The Red Sea Style." Kush 1 (1):60-86.

1955. "Suakin Postscript." Kush 3:99-111.

Meier, Prita. 2009. "Objects on the Edge: Swahili Coast Logics of Display." African Arts 42 (4):8-23.

Miran, Jonathan. 2009. Red Sea Citizens: Cosmopolitan Society and Cultural Change in Massawa. Bloomington: Indiana University Press.

Phillips, Jacke. 2011, forthcoming. "Beit Khorshid Effendi: A 'Trader's' House at Suakin.” In Proceedings of Red Sea V: Navigated Spaces, Connected Places, ed. D. Agius. Oxford: Archaeopress.

Powell, Eve Trout. 2003. A Different Shade of Colonialism: Egypt, Great Britain, and the Mastery of the Sudan. Berkeley: University of California Press.

Prestholdt, Jeremy. 2008. Domesticating the World: African Consumerism and the Genealogies of Globalization. Berkeley: University of California Press.

Rhodes, David. 2011. "The Nineteenth-Century Colonial Archaeology of Suakin, Sudan.” International Journal of Historical Archaeology 15:162-89.

Roden, David. 1970. The Decline of Suakin. Sudan Project Series No. 1. Khartoum: Sudan Research Unit.

Salim, Abdel Rahim. 1997. "Suakin: On Reviving an Ancient Red Sea Port City." Traditional Dwellings and Settlements Review 8 (2):63-74.

Scanlon, George. 1997. "Review of The Coral Buildings of Suakin: Islamic Architecture, Planning, Design and Domestic Arrangements in a Red Sea Port (London, 1995)." Journal of Islamic Studies 8:112-13.

Serjeant, R.B. 1977. "Review of The Coral Buildings of Suakin (Boston, 1976)." Bulletin of the School of Oriental and African Studies 40 (1):204-206.

Talhami, Ghada H. 1979. Swakin and Massawa under Egyptian Rule: 1865-1885. Washington DC: University Press of America.

Um, Nancy. 2010. "Reconsidering Red Sea Architecture: Building Traditions at the Hinge between the Mediterranean Sea and the Indian Ocean." Traditional Dwellings and Settlements Review Working Papers Series 226:37-60. 